www.volsu.ru

DOI: http://doi.org/10.15688/nav.jvolsu.2016.1.3

UDC 902/904(470.45)

LBC 63.444(235.54)-427.2

\title{
STATUES AND LARGE EARTHENWARE POT \\ FROM BARROW MOUND NEAR KREMENSKAYA VILLAGE ON LOWER DON: ON CONCLUDING STAGE OF MAKING OF POLOVTSIAN SCULPTURES (II) ${ }^{1}$
}

\author{
Aleksandr V. Evglevskiy \\ Donetsk National University, Donetsk, DPR (Donetsk People's Republic)
}

Evgeniy V. Kruglov

Volgograd Regional Department of All-Russian Community for Nature and Culture Monuments Protection, Volgograd, Russian Federation

\begin{abstract}
The monument is located on a low terrace above the flood plain on the right bank of the Don river and is a part of a group of barrows near the Kremenskaya village. Barrow 1 was mounded at the top of a natural $40 \mathrm{~m}-$ high hill being over $100 \mathrm{~m}$ in diameter. A complex, which consisted of two stone statues and a vessel (a large earthenware pot), was an intricate stratigraphic composition of artifacts, defined by the head of excavation V.P. Shilov as single burial 2. In fact, there were two separate pits for the Polovtsian statues and for the large earthenware pot a vessel which can be most likely dated back to the Golden Horde time. At the same time, both the critical analysis of the stratigraphy of the monument and the similarities considered enabled the authors to assume ceremonial interrelation of the statues and the large earthenware pot. Therefore, there are grounds to believe that religious monuments of the Turkic-speaking nomads of Southeastern Europe, as well as some types of statues, continued to exist in the Golden Horde time.

Key words: Polovtsian sanctuary (religious complex), late Polovtsian statues, large earthenware pot, Polovtsian steppe, Polovtsian time, epoch of the Golden Horde.
\end{abstract}

УДК 902/904(470.45)

ББК 63.444(235.54)-427.2

\section{ИЗВАЯНИЯ И КОРЧАГА ИЗ КУРГАНА У СТАНИЦЫ КРЕМЕНСКАЯ НА НИЖНЕМ ДОНУ: К ПРОБЛЕМЕ ЗАВЕРШАЮЩЕГО ЭТАПА ИЗГОТОВЛЕНИЯ ПОЛОВЕЦКОЙ СКУЛЬПТУРЫ (II) ${ }^{1}$}

\section{Александр Викторович Евглевский}

Донецкий национальный университет, г. Донецк, ДНР (Донецкая Народная Республика)

\section{Евгений Викторович Круглов}

Волгоградское региональное отделение Всероссийского общества охраны памятников истории и культуры, г. Волгоград, Российская Федерация Аннотация. Анализируемый памятник- курган 4 условной группы, расположенной около ст-цы Кре-
менская Клетского района Волгоградской области. Он находился на правом берегу реки Дон и был раскопан
в 1960 г. под руководством В.П. Шилова - начальника Астраханской археологической экспедиции ЛОИА АН
СССР. В восточной части кургана находилось половецкое святилище, обозначенное автором раскопок как
погребение 2. К сожалению, в результате несовершенной методики исследования стратиграфия памятника в
научном Отчете представлена сильно искаженной и неполной. Комплекс состоял из трех разновременных
непогребальных ям-ситуаций для двух идентичных половецких каменных скульптур, одной красноглиняной 
гончарной корчаги и примыкавшего к ним кострища. Критический анализ стратиграфии, изучение иконографии изваяний и технологии корчаги позволили установить их культовую связь. Характерные особенности скульптур, несомненно изготовленных одним мастером, позволили отнести их к группе позднеполовецких. Одна из скульптур, вероятно, была разбита монголами. Вторая была спрятана половцами в одной из ям комплекса, благодаря чему сохранилась до настоящего времени в идеальном состоянии. Корчага, скорее всего, была изготовлена в провинциальной раннезолотоордынской гончарной мастерской примерно в середине - 3-й четверти XIII века. Святилище, появившись в конце половецкого времени, продолжало функционировать и в начале золотоордынской эпохи.

Ключевые слова: половецкое святилище, поздние половецкие скульптуры, корчага, Половецкая степь, половецкое время, золотоордынская эпоха.

Хорошо известно, что количество археологических памятников кочевников предмонгольского времени в Нижнем Поволжье крайне незначительно. Особенно это касается культовых объектов - святилищ и связанных с ними изваяний, число которых буквально единично. Обнаружение рядом с изваяниями, а особенно с сохранившимися in situ, бытовых вещей - явление вообще редчайшее ${ }^{2}$, заслуживающее повышенного внимания. Именно в этой связи половецкое святилище с красноглиняной корчагой и двумя каменными изваяниями, одним целым и одним разбитым, исследованное в 1960 г. у ст-цы Кременская В.П. Шиловым, начальником Астраханской археологической экспедиции ЛОИА АН СССР, занимает особое место. К сожалению, в научный Отчет В.П. Шилов включил очень краткое описание процесса раскопок кургана 4 [Шилов, 1960а, c. 8-11]. В Приложении к Отчету им помещен план исследованного кургана с профилем западной стороны центральной бровки С-Ю, планы погребения 1 и части «погребения 2 »-ямы 1 с основанием разбитой скульптуры и ямы с корчагой (без поперечного разреза), а также включены прорисовка верхней части разбитого изваяния и черно-белая фотография корчаги после реставрации [Шилов, 1960б, с. II, табл. 2,7; с. V, табл. 1, 2; с. VI, табл. 1]. Фотография и рисунок целой скульптуры в Приложении к Отчету у В.П. Шилова отсутствуют.

Впервые о половецких изваяниях из стцы Кременская упомянул Г.А. Федоров-Давыдов в своей фундаментальной книге «Кочевники Восточной Европы под властью золотоордынских ханов». Обе скульптуры исследователь определил как мужские с изображением шлемов I типа. Целую он отнес к изваяниям типа III по собственной классификации: «...особого упрощенного стиля с объемной го- ловой, стеловидным туловом без изображения рук и ног». Стратиграфию кременских изваяний исследователь рассмотрел весьма двусмысленно и даже несколько противоречиво, но указал на очень важное значение этих находок для вопроса уточнения хронологии функционирования половецких статуй [ФедоровДавыдов, 1966, с. 185-186, 192, 266].

Несколько позже кременские изваяния оказались учтены также и в фундаментальном своде С.А. Плетневой «Половецкие каменные изваяния». По просьбе исследовательницы они были специально описаны, зарисованы и сфотографированы волгоградским археологом В.И. Мамонтовым. Упоминания о кременских изваяниях в труде С.А. Плетневой можно найти в виде ссылок на картах и в статистических таблицах, а также в каталоге половецких скульптур. Целое изваяние она определила как мужское и отнесла его к наиболее позднему типу VII по собственной классификации: стеловидные в виде «антропоидного столба», лишенные рук и ног, с тщательно выделанной головой, со шлемом типа II. Фрагментированное изваяние исследовательница определила как «практически аналогичное первому» [Плетнева, 1974, с. 12, 15, 16, 29, 64, 109, № 1272, 1273]. Вопросы стратиграфии кременских скульптур С.А. Плетнева не рассматривала. Поскольку автор раскопок В.П. Шилов предполагал лично опубликовать данный материал, С.А. Плетнева, так же, как и ранее Г.А. Федоров-Давыдов, не включила имеющиеся прорисовки и фотографии в свои графические таблицы.

Кременские изваяния не выпали из поля зрения волгоградских археологов и краеведов. В 1995 г. А.В. Ситников отнес оба изваяния к предмонгольскому времени (конец XII - начало XIII в.) и отметил, что «для них характерна детальная проработка лишь одной ли- 
цевой части, в то время как туловище трактовано в виде простого столба». Немногочисленность находок изваяний в Нижневолжском регионе А.В. Ситников объяснил тем, что по течению Нижнего Дона проходила восточная граница «Половецкой земли» [Ситников, 1995, с. 67-68]. В 2000 г. А.В. Ситников и О.В. Антюфеев выделили в регионе три хронологические группы каменной половецкой скульптуры, относящиеся: 1) к середине XI - началу XII в.; 2) XII в.; 3) концу XII - 1-й трети XIII века. Кременские изваяния были отнесены к 3-й группе [Ситников, Антюфеев, 2000, с. 57-59].

Фотография целого изваяния, отсутствующая в научном Отчете, в качестве иллюстративного материала впервые была опубликована только в 2001 г. в тематическом каталоге археологических коллекций ВОКМ [Круглов, 2001, с. 7, 22; Хабарова, 2001, с. 27]. Позднее эта же фотография переиздавалась несколько раз. В 2005 г. она была издана А.В. Материкиным и Е.В. Комиссаровой [Материкин, Комиссарова, 2005, с. 116], а позднее дважды А.С. Скрипкиным [Скрипкин, 2005, с. 144-146, рис. $45 ; 2008$, с. 157 , рис. 53 ). А.С. Скрипкин не вышел за общераспространенную верхнюю хронологическую дату времени существования половецких изваяний и отнес кременские скульптуры к концу XII - началу XIII века. Изображения кременских изваяний использовались и в коллективной монографии «Археологическое наследие Волгоградской области» [Хабарова, Петров, Кривошеева, 2013, с. 160, 280, № 384, 385].

Кременские скульптуры учитывались и в материалах «Археологической энциклопедии Волгоградской области» [Ремизов, Хабарова, 2009 , с. $122 ; 2016$, с. 120 ; Ситников, 2009, с. 198 199,214 , рис. $72 ; 2016$, с. 196-197, 212, рис. 72]. А.В. Ситников, указав на стадиальность процесса освоения половцами Волго-Донского междуречья и Нижнего Поволжья, предложил обобщающее описание нижневолжских половецких скульптур 3-й, по собственной классификации, группы, к которой он отнес и кременские изваяния: «Все указанные статуи относятся к круглой скульптуре, выполнены в технике глубокого рельефа с детальной прорисовкой головы, лица и верхней части тела. Туловище у скульптур этой группы отсутствует либо трактовано в виде столба». Определенная прими- тивность этих скульптур, по мнению автора, свидетельствует об их удаленности от основных центров половецкого мира и позволяет говорить о миграции половцев в междуречье Волги и Дона и в Нижнее Поволжье лишь в самом конце XII - начале XIII в. [Ситников, 2009, с. 198-199; 2016, с. 196-197].

Несомненно, что внимание научной общественности свидетельствовало о понимании особого значения половецких скульптур, обнаруженных в кургане у ст-цы Кременская. Тем не менее этот исключительно важный и уникальный памятник в полном объеме до сих пор не опубликован, а его научное значение остается существенно недооцененным. Необоснованная краткость и непонятность текста научного Отчета В.П. Шилова, в отдельных моментах даже противоречивость, отсутствие ряда обязательных чертежей, фотографий и прорисовок, явные ошибки, допущенные в процессе фиксации особенностей стратиграфии, мешают восприятию имеющейся информации.

\section{Общие сведения о памятнике и его стратиграфия}

В 1960 г. Астраханской археологической экспедицией ЛОИА АН СССР в Клетском районе Волгоградской (до 1961 г. - Сталинградской) области были исследованы семь курганов. Они располагались на краю высокой южной террасы правого берега р. Дон к ЮВ и В от ст-цы Кременская (рис. 1). На тот момент это были первые археологические раскопки на территории данного района ${ }^{3}$. Группу Кременская I, по В.П. Шилову, составляли четыре насыпи, три из которых (№ 2, 3 и 4) находились на расстоянии 1, 3 и даже 5 км от наиболее высокого кургана «Шпиль», получившего порядковый № 1. Фактически все эти четыре насыпи, в отличие от компактно расположенных трех курганов группы Кременская II, следует считать не общим могильником, а лишь условной группой одиночных курганов. Показательно, что в приложении к научному Отчету имеется план только группы курганов Кременская II.

Интересующий нас курган 4 группы Кременская I местные жители называли «Раскопанный курган». У его восточной полы еще 
до раскопок и были найдены высеченные из мергелевых блоков два каменных изваяния - одно целое и разбитая верхняя часть второго ${ }^{4}$. По поводу обстоятельств находки В.П. Шилов сообщил, что оба изваяния были извлечены в 1959 г. из восточной полы кургана учителем неполной средней школы ст-цы Кременская. Возможно, именно это обстоятельство и послужило основанием для проведения раскопок данной насыпи.

К моменту исследования высота кургана составляла 2 м, диаметр - 22 м (рис. 2). В связи с тем что его поверхность подвергалась многолетней распашке, первоначальная высота насыпи была несколько выше, а диаметр чуть меньше. Несмотря на довольно внушительные размеры, курган был исследован с оставлением всего лишь одной стратиграфической бровки, проходившей через условный центр насыпи по линии С-Ю [Шилов, 1960б, табл. V,1) (см. рис. 2). Согласно тексту научного Отчета верхний «распахиваемый почвенный слой» кургана имел мощность до 0,3 м; под ним располагался «темный слой дерна» - до 0,6 м; ниже шла «супесь светлосерого цвета мощностью до 1,1 м». Данная информация вызывает недоумение и первые вопросы. Каким образом слой дерна мог иметь столь внушительные размеры и находиться ниже верхнего «распахиваемого слоя»? Почему на плане не показан слой древней погребенной почвы, и с какого уровня начинался материк? На наш взгляд, более правдоподобным было бы предположение о наличии в этом кургане не одной, а двух насыпей.

В юго-западной части кургана на уровне материка была обнаружена прямоугольная яма основного погребения 1 , ориентированная по линии ЮЮЗ-ССВ (рис. 2). Длина этой ямы - 2,2 м, ширина $-1,5$ м, глубина $-1,05$ м от горизонта ${ }^{5}$. В ее засыпи на разных глубинах были встречены бронзовое шильце и четыре фрагмента глиняного лепного сосуда, позволившие отнести погребение к срубной культуре эпохи бронзы. В засыпи также фиксировались угольки, фрагменты деревянных плах от перекрытия, отдельные перегнившие кусочки дерева и пятна камыша. Дно могилы было устлано камышом.

Северо-восточный угол погребения 1 оказался прорезан более поздней ямой-ворон- кой, обозначенной в Отчете буквой «С» ${ }^{6}$. Ее диаметр около 1 м, а наибольшая глубина от горизонта составляла 0,7 м и фиксировалась за пределами северо-восточного угла ямы погребения 1. В.П. Шилов уверенно отметил, что яма-воронка «С» имела грабительский характер, именно через нее и было уничтожено основное погребение 1 [Шилов, 1960а, с. 8].

В центре кургана, в 0,5 м к СВ от погребения 1 и ямы-воронки «С», в плане кургана и разрезе бровки была зафиксирована еще одна яма, обозначенная в Отчете и на плане кургана буквой «А» (рис. 2). Она имела прямоугольную, несколько неправильных очертаний форму и, так же, как и яма погребения 1 , была ориентирована по линии ЮЮЗ-ССВ. Отдельный план этой ямы в Отчете В.П. Шилова отсутствует. Ее длина - 2,25 м, ширина - 1,75 м, что примерно совпадает с размерами ямы погребения 1. Общая глубина ямы «А» в документах четко не указана. Судя по разрезу бровки кургана и замечанию, что дно ямы находилось «на глубине 0,15 м от горизонта», она пробивала древнюю погребенную почву и уходила в материк. Следовательно, ее глубина от поверхности кургана составляла примерно 2,15 м. В.П. Шилов отметил, что на глубину 1,5 м от поверхности насыпи яма «А» была заполнена «крупными кусками мела». Судя по разрезу бровки, заполнение этой ямы не было однородным. На самом верху, прорезая «распахиваемый почвенный» и «темный дерновый» слои насыпи, располагались крупные камни, возможно, блоки или плиты; ниже их находился плотный слой относительно более мелких камней. В нижней части ямы на глубине $1,5-$ 2,15 м от поверхности камней не было. Каких-либо артефактов в виде костей, дерева или иных находок в яме «А» не зафиксировано. Лишь на самом ее дне вблизи юго-западной стенки имелись две сурчины, отмеченные на плане кургана (рис. 2).

В насыпи, на расстоянии 1,9 м к С от центра кургана и ямы «А», была зафиксирована прослойка «линзы желтой глины», обозначенная на плане кургана и разрезе бровки буквой «Б» (рис. 2). Ее размеры составляли $5 \times 9$ м, а мощность $-0,2$ м. Занимая весьма значительную площадь, эта прослойка постепенно понижалась по склону кургана и сходила на нет вблизи линии древнего горизонта. Харак- 
тер этой «линзы» В.П. Шилов не прояснил. Между тем ясно, что формирование подобной прослойки могло происходить только на некогда открытой поверхности. Понимание этого прямо указывает на существование в кургане 4 не одной насыпи, а двух. При этом видно, что «линза желтой глины» «Б» довольно четко соотносится с ямой «А» и, скорее всего, является выкидом материковых пород на поверхность первичной насыпи, сооруженной над основным погребением 1 (рис. 2). Первичная насыпь имела диаметр 14-15 м и высоту около 1,5 м. Вторичная насыпь, связанная с сооружением ямы «А», немного сместила центр кургана к СВ. Схожесть формы, размеров и ориентировки ямы основного погребения 1 и ямы «А» может свидетельствовать об их относительной одновременности или даже однокультурности.

В.П. Шилов определил характер ямы «А» как грабительский [Шилов, 1960а, с. 9]. Однако более чем вероятная связь с этой ямой материкового выкида в виде «линзы желтой глины «Б» и сооружение над ней дополнительной насыпи позволяют предполагать ее погребальное назначение. Наличие в заполнении верхней части ямы «А» камней также не позволяет считать эту яму только лишь грабительской. Действия грабителей во все времена были предельно рациональными. Свои раскопы, как правило, они оставляли открытыми. Ради чего грабителям надо было заполнять могилу камнем? Где они его брали? Почему яма, имевшая довольно значительные размеры, была заполнена по вполне определенному плану: внизу только землей, в центре мелкими камнями, а на самом верху крупными камнями, блоками или даже плитами? Что вообще могло быть объектом ограбления в этой яме? Представляется, что яма «А» - результат нескольких разновременных действий, не связанных друг с другом. К примеру, наличие двух сурчин на дне и отсутствие камней в нижней части заполнения могут свидетельствовать о том, что после ограбления яма некоторое время оставалась открытой. В таком случае заполнение ее верхней части камнями было результатом каких-то гораздо более поздних действий, не связанных ни с ее первоначальным сооружением, ни с последующим ограблением ${ }^{7}$.
На расстоянии 8 м к В от центра насыпи, на границе СВ и ЮВ секторов, в кургане 4 был зафиксирован комплекс, интересующий нас в наибольшей степени. В Отчете В.П. Шилова он был обозначен как «погребение 2» и, по словам исследователя, представлял собой две перпендикулярно расположенные по отношению друг к другу ямы (1 и 2), а также находящееся близ ямы 2 зольное пятно ${ }^{8}$ [Шилов, 1960а, с. 10] (рис. 2).

Яма 1 имела прямоугольные очертания с округлыми углами и была ориентирована по линии ЮЮЗ-ССВ. Длина ее - 2,1 м, ширина $-1,1$ м, глубина от горизонта или в материке - 0,65 м. Судя по плану ямы [Шилов, 1960б, табл. II, 2,7], у ее западной стенки в специально вырезанном углублении располагалось основание одного из двух изваяний, обнаруженных до начала раскопок лежащими у восточной полы кургана ${ }^{9}$. Высота этого фрагмента $-0,65$ м, ширина $-0,29$ м, толщина $-0,18$ м. Никаких останков человека, костей животных или иных артефактов в яме 1 не обнаружено (рис. 2).

Перпендикулярно яме 1, частично прорезая верхнюю часть ее восточной стороны, находилась ориентированная по линии 3-В яма 2 , имеющая неправильно овальные, скорее восьмеркообразные, очертания (рис. 2,2). Длина ее - 1,9 м, ширина - 0,5-0,6 м, глубина от горизонта или в материке- $0,1-0,2$ м. В западной части ямы 2 (фактически на границе между ямами 1 и 2) на глубине 0,1 м находилась красноглиняная гончарная корчага (рис. 2) ${ }^{10}$. Костей человека и животных, камней, остатков дерева или какого-либо тлена здесь также не зафиксировано. С северо-восточной стороны ямы 2, на глубине 0,1 м от «горизонта», на площади $0,25 \times 0,35$ м было зафиксировано зольное пятно подовальной в плане формы. Контуры ямы, с которой могло бы быть связано это пятно, В.П. Шиловым намечены весьма приблизительно на площади размерами 1,0 × 2,5 м [Шилов, 1960а, с. 10; 1960б, рис. V,1] (рис. 2,3). Идентичные глубины залегания корчаги и зольного пятна, возможно, свидетельствуют об общем обрядовом контексте, но прямых оснований для подобного заключения нет. При этом если ямы 1 и 2 находились в пределах насыпи на самом ее краю, то зольное пятно первоначально рас- 
полагалось уже явно за пределами кургана. Скорее всего, это были остатки не ямы, а небольшого костра с очажком, некогда разведенного рядом с курганом и позднее перекрытого распахиваемой насыпью.

\section{Ямы с мергелем/камнем на половецких святилищах}

Предваряя анализ обрядности кременского комплекса, приведем описание культовых позднекочевнических памятников с ямами, заполненными мелом или камнем, которые можно связывать также и с установкой изваяний. Это достаточно важно, поскольку изваяния и камни из ямы «А», согласно тексту В.П. Шилова, были из одного материала [Шилов, 1960а, c. $8-10]$.

Новониколаевка II, к. 3 (бассейн рек Орель и Самара). В этом кургане зафиксирована ситуация, наиболее сходная с кременским комплексом. В центре кургана обнаружена заполненная мелом большая яма $(5,75 \times 5$ м), образованная несколькими грабительскими лазами, слившимися с крупными кротовинами. Северная часть ямы заполнена слоями чистого мела, дуговидно прогибавшимися и чередовавшимися с прослойками земли. Слои мела в яме прослеживались с самого верха кургана до глубины 1,25 м на площади, вытянутой с запада на восток, размером 5,75 × 2,4 м. Яма не имела четких контуров из-за кротовин, также заполненных мелом. Дно находилось на глубине 1,7 м. Данная яма полностью разрушила основное погребение, расположенное в материке, а также находившуюся на вершине насыпи культовую площадку, о существовании которой свидетельствовало большое количество мела, оказавшегося в ее заполнении, а также остатки двух каменных изваяний 2-й половины XII - 1-й половины XIII века. Каменные скульптуры были найдены и в северной части ямы среди слоев мелового заполнения. Одно изваяние, обнаруженное с глубины 0,85 м, лежало в 0,25 м к С от центра, ничком, обращенное головой на В. Его нижняя часть находилась на глубине 1,3 м. С северо-западной стороны ниже глубины 1 м располагались фрагменты второго изваяния, также перевернутые и ориентированные на В. К С от изваяний в заполнении ямы и частично под стенками в разных местах и на разных глубинах встречались выброшенные из погребения 2 отдельные кости человека и животного, обломки керамики. Еще одно скопление мела в виде широтно ориентированного овального пятна размером $1,8 \times 1,3$ м выявлено на расстоянии 8,9 м к В от центра насыпи. Пятно находилось под пахотным слоем на глубине 0,65 м и содержало значительно меньшую концентрацию мела, чем центральная яма. Толщина слоя не превышала 0,3 м [Моруженко и др., 1983]. В отличие от кременского комплекса, вероятность принадлежности новониколаевской ямы к святилищу поздних кочевников наиболее высока.

Мечетное Поле, к. 1 (междуречье Северского Донца и Миуса/Крынки). Яма выявлена на расстоянии 2 м от центра кургана с глубины 1,8 м по характерной забутовке, состоящей из камней разрушенной обкладки кургана. Квадратная в плане яма $(2,05 \times 1,95$ м), ориентированная углами по сторонам света, была нарушена грабительской воронкой и расчищалась с глубины 2,93 м. Дно вырублено в скалистом песчаниковом грунте и устроено на глубине 3,4 м. Заполнение ямы состояло из заплывшего чернозема $u$ камней песчаника. В ее южной части выявлены лежащие без определенной системы три крупных обломка каменных изваяний, изготовленных из песчаника. В публикации А.В. Евглевского этот комплекс получил объяснение как половецкое культовое захоронение каменных изваяний [Евглевский, 1996].

Новозарьевка, к. 1 (Северное Приазовье). Наиболее поздняя четвертая насыпь кургана представляла собой слой белой глины (диаметр около 14 м, мощность 0,4-0,2 м), перекрытый черноземом мощностью до 0,5 м. По краям меловой площадки, на глубине 1,21,5 м от условного центра, встречены камни, которые как бы окружали всю эту подсыпку. На глубине 1,5 м, на расстоянии 5,8 м к Ю от центра в черноземе встречены отдельные фрагменты стенок красноглиняных средневековых амфор и обломки костей животных. Несколько южнее обнаружен овальный в плане очаг с размерами $0,4 \times 0,5$ м. Под меловой площадкой в центре кургана находилась заполненная мелом вытянутая по линии С-Ю овальная в плане яма (размеры по верху 
$2,4 \times 3,0$ м), суживающаяся книзу до глубины 1,8 м от нулевой отметки [Привалов и др., 1978]. Изваяния в кургане не обнаружены, а фрагменты амфор, найденные вне ямы, не могут являться достаточным аргументом для ее интерпретации в качестве составляющего компонента позднекочевнического святилища.

Новый, к. 67 (междуречье Дона и Маныча). Квадратная, сужающаяся ко дну яма с остатками деревянной скульптуры находилась на глубине 1,93 м в центральной части кургана и прорезала заполнение более раннего ровика. В ЮЗ углу ямы обнаружено небольшое углубление для основания скульптуры. В СВ углу лежал перевернутый вверх дном бронзовый котел. Над остатками основания скульптуры в заполнении обнаружен каменный заклад. У южного и восточного края ямы в заполнении ровика подквадратной формы зафиксированы череп и кости лошади, лежащие в беспорядке, и бронзовая пластина прямоугольной формы. Вокруг ямы со скульптурой сооружен кольцевой ровик диаметром 10,5 м [Гуркин, 1987]. Этот комплекс едва ли не единственный, который с некоторыми оговорками можно считать сохранившимся insitu. Правда, в данном случае в яме зафиксировано не каменное заполнение, а каменный заклад, что не совсем одно и то же. Тем не менее общий контекст не вызывает сомнений в принадлежности ямы к половецкому святилищу.

Попов Яр-2, к. 2 (междуречье Северского Донца и Миуса/Крынки). На дне Т-образной ямы (длина - 8,2 м) конца XIX - начала XX в., выкопанной с грабительскими целями, зафиксирован слой утоптанного черноземного грунта, засыпанного, судя по всему, вскоре после того, как была сооружена яма. В ее придонной части найден фрагмент каменного изваяния. В центральной части, под южным краем ямы, на уровне 1,60 м зафиксированы остатки кострища размерами $2,15 \times 1,5$ м. Над ним, на уровне 1,43-1,14 м, находились камни песчаника разных размеров. Над кострищем между камнями находился почти целый скелет взрослой особи КРС. На этом уровне в засыпи найдены фрагменты стеклянной бутылки XIX в., фрагмент оконного стекла и каменный оселок. На уровне $0,69-0,44$ м от ЦР центральная и южная части ямы были заполнены небольшими камнями, среди кото- рых встречались отдельные кости животных и фрагмент стенки сосуда эпохи поздней бронзы [Полидович и др., 2013, с. 46]. Интерпретировать яму с точки зрения обрядности святилища сложно.

Ростов-на-Дону, к. 6 (междуречье Северского Донца и Миуса/Крынки). На кургане 6, сооруженном в бронзовом и железном веках, было исследовано половецкое святилище. В неизменном виде под дерном сохранилась каменная конструкция в виде прямоугольника с размерами $8,5 \times 7,5$ м, ориентированная углами по сторонам света. Судя по стратиграфии, грабители дважды тревожили насыпь. Первый раз они прокопали лаз до катакомбного погребения 7 и засыпали его грунтом темно-серого цвета. Во второй раз перекоп оказался неглубоким - 1,4 м, его заполнение черного цвета. В результате повреждений насыпи все находки оказались в переотложенном состоянии. В заполнении более раннего перекопа найдена каменная скульптура, сброшенная с поверхности кургана. В этом же слое обнаружены остатки костей двух человек и обломок каменного терочника, но эти находки, скорее всего, относятся к разрушенному катакомбному погребению. В слое позднего перекопа найдено множество обломков известняка, угли, кости животных и три фрагмента красноглиняных сосудов. Один из них часть дна баклажки салтово-маяцкой культуры, происходящей с кочевья, расположенного вблизи кургана [Волков, Ларенок, 1988]. Связывать яму и изваяния с тем или иным обрядовым контекстом затруднительно.

Водяное, к. 2 (Северное Приазовье). В кургане не найдены изваяния, но обнаружены две культовые ямы эпохи Средневековья. Стоит обратить внимание на округлую в плане яму 1 , диаметром 1,1 м, расположенную в центре кургана, прослеженную в материке на глубине 0,6 м от вершины. Заполнение представляло каменную забутовку, в которой встречались фрагменты средневековой амфоры, отдельные кости животных и древесные угольки. На дне, на глубине 1,9 м, сохранились следы очажка в виде овального в плане пятна диаметром 0,4 м [Привалов и др., 1978]. Несмотря на находки фрагментов амфор, сомнения в принадлежности ямы 1 культовому объекту поздних кочевников остаются. 
Бешпагир, к. 2, п. 9 (Северо-Восточное Предкавказье). В центре ямы, сооруженной в ЮВ части кургана, обнаружено вертикально стоящее в материке каменное изваяние, причем закопана была только его нижняя необработанная часть, сопровождавшаяся жертвоприношением двух человек. Примечательно, что изваяние находилось на значительной глубине; так, голова зафиксирована на уровне 1,98 м. Яма яйцевидной формы, ее длина - 2,04 м, ширина - 11,64 м, глубина -3,37 м, ориентирована по линии С-Ю. В гумусированном заполнении встречались одиночные мелкие камни, а начиная с глубины 3,09 м (от колен до основания изваяния) уже вся яма была засыпана мелкими камнями. Особенно много их на скелетах и вокруг изваяния на глубине 3-3,2 м [Гугуев, Мирошина, 2002]. Это, пожалуй, наиболее ясный случай сооружения ям с камнем на святилищах, но ее обрядовое сопоставление с кременским комплексом несколько проблематично.

Новоселовка, к. 2 (Северное Приазовье). На древней насыпи, на уровне $0,7-1,0$ м от ЦР, располагалось каменное сооружение. В центральной части обнаружены два каменных изваяния, одно из них - в 2 м к Ю от ЦР, на уровне 0,59 м. Основание второго находилось в 3,15 м к Ю, на уровне 0,56 м. В 7,15 м к Ю от репера найден фрагмент третьего изваяния, основание которого зафиксировано в восточной поле кургана [Швецов, 1979, с. 203]. Установку нескольких скульптур на одном святилище, как в центральной части кургана (несколько смещенной к югу), так и в восточной поле, можно объяснить двумя версиями. Первая - так было изначально предусмотрено обрядовой процедурой, вторая - одно из изваяний, стоявшее ранее в центральной части кургана, со временем переставили в восточную полу. Однако, в отличие от ситуации на святилище у ст-цы Кременская, здесь версия о возможной перестановке одного из изваяний подкрепляется фактом наличия вкопанного основания другого изваяния в центральной части кургана. Правда, автор публикации по этому поводу пишет, что изваяние (непонятно какое), «по-видимому, ранее находилось на другом кургане, поскольку обломки найдены разбросанными среди камней, упавших со стен святилища» [Швецов, 1979, с. 204], что также не следует сбрасывать со счетов.
Итак, ни одна из вышеуказанных ям из культовых позднекочевнических комплексов с точки зрения обрядового контекста не является близкой аналогией и не позволяет прояснить вопрос культурной идентификации заполненной мергелем ямы «А» из кременского кургана. До появления новой информации ямы из восточной полы кургана с обломком основания изваяния и корчагой с ямой «А» можно связывать лишь теоретически.

Что касается размещения изваяний в восточной поле кургана, то для культовых памятников кочевников это типичная ситуация для всей евразийской зоны степей, а не только для Восточной Европы. Примерно две трети изваяний находились именно в восточных секторах курганов, преимущественно в восточной поле. Фиксация в кременском кургане изваяний и связанной с ними культовой площадки свидетельствует о существовании общетюркского культа восходящего солнца. Все без исключения изваяния, обнаруженные in situ, ориентированы в восточный сектор небосвода. Удивляет лишь то, что среди более 230 ныне известных восточно-европейских культовых курганов с изваяниями «поздние» типы скульптур встречены лишь трижды. Кроме памятника у ст-цы Кременская, это еще и курган у хут. Матяшов на Нижнем Дону и Петровское в Северном Приазовье. Всего три изваяния относятся к «ранним» типам, все остальные - к «развитым».

\section{Описание изваяний и корчаги}

Изваяние 1 (целое) мужское, прекрасной сохранности ${ }^{11}$, высечено из мергеля ${ }^{12}$ (см. рис. 3,4$)$. На голове, по-видимому, изображен шлем полусферической формы с навершием, показанный крайне схематично и неестественно приземистым. Поэтому нельзя полностью исключать того, что это не шлем с навершием для плюмажа, а шапочка с утолщением на макушке (кисточкой). В отличие от шлема/шапочки, лицо смоделировано более объемно, искусно, тщательно и реалистично. Веки трактованы в виде валиков, обрамляющих выпуклое глазное яблоко. Зрачки обозначены прочерченными крестиками, что является уникальным. Нос длинный, прямой, с заметным расширением. Ушные раковины по- 
казаны в виде вертикальных валиков, вытянутых книзу, с углублением в центре. Губы выделены слегка изогнутыми рельефными линиями, чуть продленными влево так, что рот выглядит несколько скошенным. Лицо полное, одутловатое. Подбородок округлен, хорошо выражен.

Плечи едва намечены, покатые. Торс четырехугольный (почти квадратный) в сечении столб, без изображения рук и ног. Хорошо видны небольшие кружочки-выпуклости, имитирующие груди. Пупок с выпуклой точкой в центре трактован более крупно, чем миниатюрные груди (рис. 3,7). О спине судить практически невозможно, поскольку изваяние в настоящее время установлено почти вплотную к стене. На этом типе скульптуры могла быть изображена коса, но на ощупь ее там нет. Прощупываются лишь неглубокие ямки, видимо оставшиеся от выравнивания тыльной стороны скульптуры. Высота изваяния 1,25 м, ширина $-0,25$ м, толщина $-0,23-0,25$ м. Тщательно заполированная поверхность лицевой и боковых сторон имеет серую благородную патину, в связи с чем техника изготовления не просматривается.

Изваяние 2 (разбитое) мужское. Сохранилась только голова с верхней частью торса (до уровня груди), разбитая на 4 части [Шилов, 1960б, табл. V,2] (см. рис. 5). Правая часть лица отбита, тем не менее можно говорить, что иконографически и портретно данное изваяние исключительно близко первому. Правда, глаза показаны без зрачков. На тыльной стороне скульптуры косы отсутствуют. Поэтому с большой долей вероятности можно говорить, что и на целом изваянии коса также отсутствует. Высота сохранившегося фрагмента - 0,6 м, ширина $-0,3$ м, толщина $-0,3$ м.

Корчага. Красноглиняный грушевидной формы сосуд с петлевидной ручкой, гофрирован на плечиках двумя, а в нижней части тулова - четырнадцатью круговыми бороздками. На шейке просверлено отверстие диаметром 0,5 см. Поверхность красновато-оранжевого цвета, тщательно заглажена. Черепок в изломе светло-красный, с включениями частиц извести. Днище слегка вогнутое. Высота сосуда -33 см, диаметр отогнутого наружу венчика - 13,5 см, наибольший диаметр тулова 22,8 см, диаметр днища - 12,5 см (см. рис. 6).

\section{Анализ «погребения 2»}

Яму 1 с разбитым изваянием и яму 2 с корчагой В.П. Шилов посчитал одним погребением [Шилов, 1960а, с. 10]. Опираясь на факт обнаружения в яме 1 основания (нижней части) разрушенного изваяния, исследователь заключил, что его верхняя часть и второе (целое) изваяние первоначально находились гдето «над могилой, которая оказалась полностью ограбленной при раскопках местного учителя». Данное замечание В.П. Шилова также требует комментария. Во-первых, нижняя и верхняя части разбитого изваяния друг с другом не состыковываются. Поскольку каких-либо иных обломков не обнаружено, полной уверенности, что эти фрагменты действительно происходят от одного изваяния, нет. Это лишь наиболее вероятное предположение, условно принимаемое всеми исследователями, в том числе и нами. Во-вторых, не совсем понятно, каким образом ямы 1 и 2 оказались «полностью ограблены» раскопками учителя, но при этом не была обнаружена весьма массивная корчага, расположенная как раз между ямами.

В отличие от В.П. Шилова, Г.А. Федоров-Давыдов поступил более осторожно и не объединил в один комплекс изваяние и корчагу, справедливо считая ямы «погребения 2» разновременными. Он отметил, что в «погребении 2» яма 1 с основанием разбитого изваяния - «основная», а прорезавшая ее яма 2 с корчагой - «впускная». Однако исследователь не вполне ясно выразился относительно характера ямы 2. На одной странице он указал, что яма с корчагой являлась «впускным ограбленным погребением» [Федоров-Давыдов, 1966, с. 186], а на другой написал, что «признаков погребения не было обнаружено. Как и в курганах Чокрак и Средняя Аюла, здесь было, видимо, не погребение, а остатки культа, посвященного изваяниям, поставленным на более раннем кургане, вероятно, перед ямой. Позднее яма была засыпана, а изваяния сломаны» [Федоров-Давыдов, 1966, с. 192]. Несомненно, неопределенности полевой документации не могли не повлиять на отдельные выводы Г.А. Федорова-Давыдова, но его научная интуиция и опыт способствовали формированию несколько иного понимания стра- 
тиграфических и хронологических позиций кременских ям, изваяний и корчаги.

Действительно, если яма 2 с корчагой, согласно отчетным данным, прорезала яму 1 с основанием разбитого изваяния (рис. $2,1,2,4$ ), то прямая стратиграфия предельно четко и ясно указывает на разную относительную хронологию обеих ям и корчаги. При этом разница во времени их сооружения могла быть как предельно короткой, так и весьма значительной.

Не менее спорными и расплывчатыми следует считать формулировки В.П. Шилова и Г.А. Федорова-Давыдова об «ограблении» «погребения 2» и археологическом характере данного объекта. Если не считать нещадного разрушения одного изваяния и возможного, но ничем не обоснованного предположительного разрушения ям 1 и 2 , совершенно непонятно, что и кем здесь было ограблено или разрушено. Опираясь на современную источниковую базу исследованных курганов с изваяниями, с большой долей вероятности можно предполагать, что кроме скульптур и корчаги в этих ямах первоначально ничего больше не было. На основании четко установленных фактов из других культовых курганов поздних кочевников можно допустить, что одно из изваяний могло быть разбито в ритуальных или иных целях самими кочевниками еще в древности. Поэтому для однозначного утверждения, что «погребение 2 было ограблено», нет никаких оснований.

По своим характеристикам ни яма $1 \mathrm{c}$ основанием разбитого изваяния, ни яма 2 с корчагой не являются классическими «погребениями». Никаких останков человека, костей животных, иных артефактов или хотя бы их следов, за исключением основания изваяния в яме 1 и корчаги в западной части ямы 2 , не обнаружено. Сами ямы располагались у кромки восточной полы кургана на участке, не характерном для мест совершения позднекочевнических захоронений. Яма 2 имела форму, нетипичную для таких погребений. Соотношение длины и ширины $(1,9 \times 0,5-0,6$ м) также не было характерным для них. В первой версии анализа кременского комплекса один из авторов полагал, что нестандартные формы ям 1 и 2 были результатом разрушения, возможно, уже в новейшее время [Евглевский, 2014 , с. 270]. Однако можно предложить и иное объяснение. Более чем вероятно, что яма «погребения 2» представляла собой не одну, а две наложившиеся друг на друга ямы - «западную» и «восточную». «Западная» имела округлую форму диаметром $0,55-0,6$ м, в ней находилась корчага. «Восточная» - овальная по форме с размерами $1,4 \times 0,5-0,6$ м. При таком понимании отпадает необходимость объяснения специфической формы ямы 2 , а «погребение 2» оказывается условным комплексом, состоящим не из двух, а из трех ям и примыкающего к ним кострища, являющихся разновременными относительно друг друга культовыми «ситуациями» непогребального характера, связанных друг с другом общим контекстом половецких изваяний.

Для максимально правильного понимания особенностей кременского комплекса, насколько это вообще возможно, необходимо обсудить еще несколько крайне важных вопросов. Где местный учитель мог бы выкопать верхнюю часть разбитого изваяния и целую статую? Являлись ли эти места первоначальным расположением данных скульптур? Почему одно из изваяний было разбито, а второе сохранилось практически в идеальном состоянии?

Как уже отмечалось, автор раскопок довольно двусмысленно указал, что выкопанные учителем изваяния первоначально находились где-то «над могилой» [Шилов, 1960а, с. 11]. Напомним, что в «погребении 2» максимальная глубина ямы $1-0,65$ м, а глубина ямы 2 была и того меньше - 0,2 м. Понятно, что каменные скульптуры совсем не обязательно были выкопаны единовременно из какого-то одного места. Но совсем не обязательно и то, что этим местом непременно должна быть, казалось бы, чуть более подходящая по своим размерам яма 1 , как первоначально полагал один из авторов [Евглевский, 2014, с. 267]. На дне ямы 1 в специально вырезанном для особой устойчивости углублении in situ было найдено основание лишь одной разбитой скульптуры. Это говорит о том, что только эта статуя, да и то с оговорками (см. выше), сохранила прямое указание на свое первоначальное расположение. Указаний на возможность первоначального местонахождения в яме 1 также и целого изваяния - нет.

Верхняя часть разбитого изваяния до момента разрушения, скорее всего, находи- 
лась над землей в вертикальном положении и некоторое время являлась открытой для свободного обозрения и доступа. Это время могло занимать промежуток от одного дня до нескольких десятков лет. Сам факт разрушения изваяния на месте его установки как раз и подтверждает такую версию. Следовательно, первичная функция этой скульптуры была вполне традиционная, культовая. После разрушения разрозненные обломки верхней части, скорее всего, располагались бессистемно на поверхности кургана или на некоторой глубине в пахотном слое. Большая их часть, вероятно, в процессе распашки насыпи была просто утрачена. Местонахождение перемещенных фрагментов достоверно вряд ли вообще может быть определимо, но в данном случае это и не столь принципиально. Гораздо интереснее и важнее другое: высота основания разбитой скульптуры, сохранившейся в яме 1 (0,65 м), совпадает с глубиной самой ямы, что вряд ли может быть простой случайностью. Наземная часть «пострадавшего» изваяния, вероятнее всего, была срезана «под корень» по линии дневной поверхности, хотя, казалось бы, гораздо проще было бы выкопать все изваяние целиком. Погромщики либо не имели соответствующего инвентаря, либо не были знакомы с конструкцией половецких изваяний. Но в данном случае более важно то, что заглубленная часть уничтоженной ими каменной скульптуры, по-видимому, их вообще не интересовала.

Сложнее обстоит дело с определением места первоначального размещения целого изваяния. Один из авторов ранее полагал, что целое изваяние до обнаружения его учителем находилось в яме 1 вместе с основанием разбитой статуи [Евглевский, 2014, с. 267]. Но поводов для такого заключения по большому счету нет. Но и других мест, специально подготовленных для установки в вертикальном положении также и второго изваяния, в кургане 4 тоже нет. Поэтому нельзя исключать того, что изначально целое изваяние могло вообще не находиться в кургане 4, а было перемещено сюда откуда-то со стороны. Но в этом случае гораздо более важно наблюдение, что это изваяние имело «прекрасную сохранность» [Евглевский, 2014, с. 264] и оно не носило на себе следов негативного внешнего воздействия. Практически все его повреждения - со- временные и связаны лишь с вынужденными неоднократными перемещениями из одного музейного помещения в другое. В древности это изваяние не было «разбито», и оно «не использовалось во вторичных целях для строительства кургана и устройства могилы», как почему-то совершенно ошибочно полагал Г.А. ФедоровДавыдов [Федоров-Давыдов, 1966, с. 186]. В отличие от разбитой скульптуры, оно либо вообще не предназначалось для свободного обозрения, либо по каким-то причинам не получило такую возможность. Вероятнее всего, это изваяние с самого начала попросту было укрыто в насыпи кургана, так как иначе оно также оказалось бы уничтожено или повреждено. В таком случае функция целого изваяния в кургане 4 была несколько иная, чем у изваяния, обнаруженного разбитым. Представляется, что в комплексе нескольких ситуаций «погребения 2» восточная часть ямы 2 специально предназначалась для размещения в ней целого изваяния. И именно отсюда, скорее всего, целое изваяние и было извлечено местным учителем. Расположенную рядом корчагу он мог просто не заметить. Естественно, что в восточной части ямы 2 скульптура могла располагаться лишь в горизонтальном «лежачем» положении, что и уберегло ее от разрушения. Очевидно, что не только отдельные части каменной половецкой пластики, но и целые предметы, скрытые в земле, погромщиков, скорее всего, уже не интересовали. Данное предположение позволяет объяснить специфическое местоположение также и глиняной корчаги. Найденная между двумя ямами-ситуациями, в каждой из которых располагалось по одному изваянию, она лишь формально находилась «как в одной, так и в другой яме» [Евглевский, 2014, с. 270]. Фактически корчага и изваяния располагались в «собственных» ямах. При этом нам понятно только соотношение ямы 1 с основанием разбитого изваяния и ямы с корчагой. Стратиграфия «западной» и «восточной» частей ямы 2 остается, к сожалению, неясной. В связке разновременных ям-ситуаций «погребения 2» наиболее ранней («основной»), как и предполагал Г.А. Федоров-Давыдов, действительно является яма 1, а яма 2, в целом, более поздняя. Не очень понятно, можно ли считать «восточную» часть ямы 2 преднамерен- 
ным тайным захоронением целого изваяния и сохранялась ли в момент предания его земле наземная часть другого изваяния, но само сооружение «восточной» части ямы 2 рядом с ямой 1 не могло быть простой случайностью, и культовая связь между ними несомненна. Во время разрушения открыто стоящего изваяния второе либо еще отсутствовало в кургане, либо уже было надежно закопано. Данное предположение - единственное, позволяющее объяснить, почему одна скульптура была нещадно разбита, а вторая практически не получила никаких повреждений.

Сложнее обстоит дело с корчагой из «западной» части ямы 2. Здесь возможны два равносильных варианта объяснения. Корчагу могли закопать на краю ямы 1 как до сооружения «восточной» части ямы 2 с целым изваянием, так и уже после этого. В обоих вариантах корчага достоверно более поздняя только относительно ямы 1 с основанием разбитого изваяния. Но если в первом варианте она является условным «подношением» только одному изваянию, то во втором должна была предназначаться сразу обеим скульптурам.

В.П. Шилов, не приводя никаких аргументов, впрочем и не требующихся для Отчета, весь комплекс «погребения 2» датировал золотоордынским временем. Вероятнее всего, он опирался на факт обнаружения весьма специфической красноглиняной корчаги, очень похожей на золотоордынскую посуду [Шилов, 1960а, c. 11]. Практически не сомневался в золотоордынской дате корчаги и Г.А. Федоров-Давыдов, но свое мнение он высказал уже более чем осторожно: «Оно [«яма-погребение 2»] по характерной корчаге с горизонтальной гофрировкой нижней части тулова, типичной для посуды Нового Сарая, Увека и других золотоордынских городов, может быть датировано примерно (выделено нами. - A. E., E. K.) золотоордынским временем. Так как это погребение пересекает яму с основным погребением [яму 1], то очевидно, что и главное погребение не моложе XIII-XIV вв., а следовательно, статуи, разбитые при сооружении этой могилы, также относятся ко времени не позднее золотоордынской эпохи, а скорее всего (выделено нами. - A. E., E. K.), - к домонгольской, поскольку в этот период они были разбиты и использованы при строительстве кур- гана и устройстве могилы, то есть утратили свои функции» [Федоров-Давыдов, 1966, с. 186]. Отметим, что Г.А. Федоров-Давыдов в процитированном фрагменте почему-то сразу обе статуи посчитал разбитыми, возможно, что к моменту написания своих строк самих скульптур он еще не видел. Но исследователь мог не видеть также и корчагу и в ее анализе опираться лишь на черно-белое фото из Отчета. В вышеприведенной весьма противоречивой цитате нет развернутой атрибуции корчаги и конкретных ссылок на аналогии, не приведены аналогии и изваяниям. Вероятно, такая задача исследователем не ставилась, либо исходный материал был не полностью доступен и понятен.

Так или иначе, точка зрения Г.А. Федорова-Давыдова послужила одним из основных аргументов выделения наиболее поздней группы восточно-европейских половецких изваяний (упрощенных, по его типологии). Материал, появившийся с тех пор в результате масштабных раскопок на Нижнем Дону, в Нижнем Поволжье и других районах, в настоящее время дает возможность более детально проанализировать эту все еще не очень ясную ситуацию, конкретизировать некоторые особенности типологии позднеполовецких изваяний и уточнить хронологические границы их использования. Особенности кременского комплекса существенно помогают решению некоторых из этих вопросов. Их рассмотрение наиболее актуально именно в подобном контексте, поскольку среди специалистов до сих пор господствует мнение, что с приходом монголов восточно-европейские кочевники почти автоматически прекращают изготовление изваяний, перестают функционировать также и их родовые святилища. Но процесс изживания традиции почитания родовых изваяний у половцев не мог быть однодневным и простым явлением. Мы видим, что уже крайне осторожная датировка кременской корчаги Г.А. Федоровым-Давыдовым, признанным специалистом по керамике Золотой Орды, в виде витиеватой формулировки «примерно золотоордынским временем» автоматически давала основание усомниться в его собственной концепции относительно хронологии поздней группы изваяний упрощенного стиля типа III по Г.А. Федорову-Давыдову [Федоров- 
Давыдов 1966, с. 168], типа VII по С.А. Плетневой [Плетнева 1974, с. 69].

В целом, Г.А. Федоров-Давыдов всю половецкую скульптуру не выводил за пределы предмонгольского времени. Он писал, что «собранные факты позволяют датировать каменные изваяния II-III периодами, то есть XII началом XIII в.» [Федоров-Давыдов, 1966, c. 186]. Однако, ссылаясь на сообщение Рубрука, исследователь противоречил сам себе: «Наша датировка каменных изваяний подтверждается письменными сообщениями. Рубрук, посетивший половецкие степи в середине XIII в. (то есть уже в раннезолотоордынское время), писал, что у команов имеется обычай ставить каменные статуи на курганах» [Федоров-Давыдов, 1966, с. 186]. В данном случае, при всей противоречивости дневников Рубрука, вряд ли есть смысл ему не доверять. Ведь Рубрук в этом пассаже не пишет о деталях давно ушедшего прошлого, которые в разных локальных зонах могли быть различными, а сообщает общеизвестный и, очевидно, вполне реальный факт. Но именно эта реплика путешественника послужила одним из оснований для постановки вопроса необходимости более детального уточнения даты кременского комплекса.

Решительные, хотя и не вполне аргументированные и далеко не бесспорные шаги для положительного решения вопроса о принципиальной возможности изготовления и функционирования половецких изваяний, также и в раннезолотоордынское время, сравнительно недавно сделал Е.И. Нарожный [Нарожный 2003, c. 246-250]. Поэтому на эмпирическом уровне кременские изваяния вполне можно относить как к половецкому (XII - 1-я четверть XIII в.), так и к золотоордынскому времени (2-я четверть XIII - XIV в.). Чтобы обосновать более точную дату всего комплекса, необходимо провести анализ иконографии скульптур, основных стилеобразующих признаков и технических приемов их изготовления. Другим важнейшим вопросом является прояснение хронологических позиций корчаги.

\section{Анализ корчаги}

Как уже отмечалось, находки керамики в культовых курганах поздних кочевников - явление чрезвычайно редкое. Амфоры или их фрагменты находят примерно в 4 раза чаще корчаг, датируются они относительно более ранним временем, нежели корчаги. Находки корчаг фиксируются лишь в виде фрагментов, обычно обнаруживаемых (как и амфоры) в ровиках или в насыпи. Таких памятников (кроме Кременской) известно 4, все они расположены в междуречье Днепра и Молочной.

В Каирке, к. 1, в районе ровика и на поверхности насыпи обнаружены обломки красноглиняной корчаги, связанные с тризной. Яма для изваяния, как и в Кременской, находилась в восточной части насыпи на глубине $0,7-0,8$ м от поверхности. Изваяние женское, стоящего типа, изготовлено в стиле горельефа [Кубышев и др., 1986].

В Новомихайловке, к. 3, развал красноглиняной корчаги с утраченной придонной частью обнаружен вокруг мужского изваяния, изготовленного из известняка. Венчик вертикальный, от него отходят две дуговидные ручки, крепящиеся к плечикам. Верхняя часть корчаги покрыта продольным рифлением. Диаметр венчика - 7 см, диаметр плечиков 40 см [Кубышев и др., 1985].

В Громовке, к. 1, фрагмент средневековой рифленой корчаги найден в заполнении рва среди остатков тризны - костей животных. Изваяние на кургане не обнаружено, возможно было вывезено [Кубышев и др., 1985].

В Сивашовке, к. 8, фрагменты корчаги найдены на различной глубине в заполнении ровика у его восточной перемычки. Один из фрагментов имел «процарапанный знак в виде латинской буквы». В С3 части насыпи обнаружен фрагмент каменного изваяния, изготовленного из серого плотного ракушечника [Кубышев и др., 1980].

Таким образом, информация о находках фрагментов корчаг в культовых курганах кочевников есть, но она имеет не более чем статистический характер. Находки изваяний из вышеупомянутых памятников также не уточняют датировку кременского комплекса.

Аналогий, но не совсем точных, кременской корчаге в настоящее время известно достаточно много. Сходные формы сосудов есть в Волжской Булгарии, Нижнем Поволжье, на Нижнем Дону, Северном Кавказе и даже в Закавказье. Чтобы не ошибиться с определени- 
ем места и времени производства, аналогии следовало бы искать не только по морфологическим, но и по технологическим признакам. К сожалению, комплексный поиск из-за отсутствия лабораторного анализа теста сосуда и опыта работы с керамикой данного круга провести нам пока не удалось. В этих условиях одним из важных элементов анализа корчаги оказались частные консультации одного из авторов с И.В. Волковым ${ }^{13}$. По мнению этого исследователя, кременская корчага «больше всего напоминает вторую группу керамики Нижнего Поволжья или Азака. Белесые высолы на поверхности сосуда гораздо больше характерны для Нижнего Поволжья, чем для Азака. Возможно, корчага была изготовлена в Сарай-Бату или Сарай ал-Джадид, но не исключены и ближайшие к ним золотоордынские памятники. Однако вероятность ошибки все же достаточно высока. Из-за слабого разрешения фотографий и замазки гипсом шероховатости от песка плохо видны на поверхности сосуда. По той же причине несколько странно выглядит то, что на корчаге есть нечто, напоминающее зерна карбонатов в фасетках. $<\ldots>$ На внешней поверхности нижней трети высоты в районе спирально-жгутового налепа видны своеобразные волны (рис. 6,14), которые обычно образовываются при вытягивании сосуда на круге. Бросающаяся в глаза зольная подсыпка на дне (рис. 6,7) является признаком изготовления корчаги с помощью спирально-жгутового налепа. Это означает, что данный сосуд сравнительно низкого уровня. Но не факт, что корчага обязательно является продукцией кустарного производства или же изготовлена каким-то неопытным гончаром. <...> В целом, так называемые тянутые сосуды характерны для 2-й половины XIV в., во всяком случае, не ранее 2-й четверти XIV века. На Дону и Кубани есть только лепные сосуды со спирально-жгутовым налепом на круге, тянутые сосуды есть на Нижней Волге, но их очень мало» ${ }^{14}$.

По своим индивидуальным характеристикам кременская корчага не относится к числу широко распространенных, она, можно сказать, является уникальным сосудом. Сочетание признаков горла, присущих корчаге, чаще всего можно встретить на посуде из Волжской Булгарии. В других регионах такая посуда представлена незначительно. Необычен нижний прилеп ручки (вторая отбита, видны следы, см. рис. 6,5), имеющий острый угол с плечиком. Следовательно, дополнительного жгута изнутри для более прочного соединения ручки с туловом не было. Данная особенность исключительна для степей Юго-Восточной Европы, а потому изготовление сосуда по этому признаку можно связывать как с Нижней Волгой, так и с Крымом, где такая технология имела место быть. Сечение ручки больше напоминает особенности ручек корчаг Крыма.

Учитывая общий контекст находки корчаги рядом с изваяниями, датировка XIV в. маловероятна, хотя датировку рубежом XIIIXIV вв. полностью исключать нельзя. Это вполне возможно, если предположить, что сосуд поместили (случайно или намеренно в качестве пожертвования) вблизи изваяний спустя какое-то значительное время уже после их установки. Любому кочевнику была хорошо известна ключевая роль в иконографии изваяний, которая придавалась сосуду. Поскольку сосуд на самих изваяниях не показан, установка корчаги в виде подношения могла быть своеобразным его заменителем (восполнением иконографии, фактом памяти культуры). Но если это действительно так, то помещение корчаги в землю было не очень сильно отдалено от времени размещения в кургане самих изваяний и должно было, как минимум, совпадать со временем остаточной жизни одного и того же поколения, - люди элементарно должны были сохранять в своей памяти такие важные обрядовые особенности.

Судя по корчагам из Волжской Булгарии [Кокорина, 2002, с. 56-59, рис. 25-26; с. 120-134, рис. 69-70, 93], дата кременской находки может определяться не только в рамках XIII 1-й четверти XIV в., но относиться также и к XII веку. Сосуд близкой формы был обнаружен на Алексеевском городище, который Т.А. Хлебникова датирует X-XI вв. [Хлебникова, 1984, c. 138 , рис. 60,1$]$, а на селище Рождественское аналогии относятся к XII - началу XIII в. [Хлебникова, 1984, с. 180 , рис. 96,4 ; с. 212 , рис. 119 - см. сводную хронологическую таблицу). Однако датировка корчаги XII в. также маловероятна, поскольку в домонгольское время подавляющее большинство керамики 
Волжской Булгарии изготавливалось со сплошным лощением, а на кременском сосуде лощения нет. Кроме того, если формы корчаг домонгольского и ордынского времени не имеют принципиальных различий, то венчики XII - начала XIII в. (I группа - по Т.А. Хлебниковой) более массивные, нежели на нашей корчаге [Хлебникова, 1984]. Косвенный, но не менее важный аргумент в пользу такого заключения - в погребениях кочевников половецкого времени корчаги ни разу не были встречены.

Таким образом, поиск аналогий кременской корчаге логичнее ограничить лишь материалами XIII - 1-й четверти XIV века. К сожалению, аналогий с точностью до деталей найти так и не удалось. Одна из причин этого состоит в том, что в XIII - 1-й четверти XIV в. в степной полосе Восточной Европы работало множество маленьких мастерских на местной глине, с небольшим объемом производства, со своими традициями и технологическими особенностями. Поддержкой версии о раннеордынской дате может быть и то, что в раннезолотоордынских и особенно позднезолотоордынских напластованиях городищ и селищ Волжской Булгарии наблюдается весьма ощутимое увеличение количества корчаг. Но корчаги раннезолотоордынского слоя в Болгаре в основном сохраняют формы домонгольского времени. Новые признаки начинают появляться и становятся характерными только лишь у позднезолотоордынских корчаг [Хлебникова, 1988, с. 79].

Вышесказанное позволяет уверенно исключить из датировки корчаги не только XII в., но и практически весь XIV век. Более того, сравнение по компонентам формы и техническим приемам изготовления приводит к выводу, что верхнюю границу стоит опустить до 3-й четверти XIII века. Именно с этого времени на золотоордынской территории корчаги начинают интенсивно видоизменяться. Во всяком случае, это характерно, как минимум, для Волжской Булгарии и Среднего Поволжья.

Против крайних дат (XII и XIV вв.) и возможной локализации мест изготовления корчаги в развитых в керамическом отношении городах выступает тот факт, что в домонгольское время в Волжской Булгарии, в частности в Биляре и Суваре (Кузнечинское городище), как и в других регионах, обнаруживается, на первый взгляд, странная вещь. В домонгольское время вся керамика там высокотехнологичная, тянутая. А в ордынское время уровень технологии резко падает, и почти вся керамика, кроме небольших сосудов, сделана спирально-жгутовым налепом с заглаживанием на круге. Именно поэтому бороздок от вытягивания в нижней части тулова, таких как на корчаге из ст-цы Кременская, в Волжской Булгарии найти не удалось. Кстати, нигде нет (во всяком случае, в Волжской Булгарии) и следов от ладони на верхней части плечика ${ }^{15}$. Не вполне характерен для корчаг Волжской Булгарии и венчик.

Учитывая оригинальные морфологические и технологические особенности кременской корчаги, а также некоторый круг аналогий, регион ее изготовления предпочтительнее локализовывать в небольшой зоне вокруг места самой находки (во всяком случае, вряд ли дальше Нижнего Дона). Вероятность того, что столь оригинальный и в то же время относительно несовершенный сосуд мог быть привезен из развитых в керамическом отношении центров производства, какими являлись, например, Сарай-Бату и Сарай ал-Джадид, на наш взгляд, невысока.

\section{Анализ изваяний и проблема хронологии позднейших половецких скульптур}

Поиск аналогий. Относительно близкие аналогии кременским изваяниям представлены в коллекции половецких скульптур Саратовского историко-краеведческого музея ${ }^{16}$. Все саратовские изваяния (кроме одного столбовидного, точнее четырехгранного в сечении) стеловидного типа (прямоугольные в сечении), мужские. Руки и ноги не показаны, то есть они не полнофигурные. У одного изваяния (рис. 7,1 ) изображен пупок, как и на целом изваянии из ст-цы Кременская. На головах у всех изваяний (за исключением одного), по мнению С.А. Плетневой, изображены шлемы [Плетнева, 1974, с. 109], причем у трех из них они (как и на кременских) довольно приземистые. Если не знать иконографическую традицию изображать на мужских изваяниях развитого половецкого времени (2-я половина 
XII - начало XIII в.) практически лишь одни шлемы, то можно было бы принять головные уборы на некоторых изваяниях за шапочки. На изваянии (рис. 7,1) шлем практически идентичен шлему/шапочке скульптуры из ст-цы Кременская.

Портретность кременских изваяний, в сравнении с саратовскими, на порядок выше. Возможно, причиной такого восприятия являются повреждения на лицах статуй из музейной коллекции, но все же последние выглядят более унифицированно, нежели лица на кременских скульптурах (особенно это касается изображений носов).

Если груди в виде маленьких кружочков, изображенные на одном из кременских изваяний ${ }^{17},-$ признак относительно распространенный для XI-XII вв. (особенно на Урале), то рельефный пупок - иконографическая редкость. Из всего массива изваяний Евразийских степей сочетание таких антропологических деталей нам известно лишь в одном случае - на находке у с. Сергеевка Алматынской области (Юго-Восточный Казахстан) [Шер, 1966, табл. XXVI,124] (рис. 7,5).

Сочетание шлема/шапочки (близких кременским изображениям) с кружочками-грудьми имеется на изваянии из святилища Шольсай-1 (горная местность Мерке на Тянь-Шане) из Юго-Восточного Казахстана, определенного А.М. Досымбаевой как женское. У него, кроме прямоугольного (почти квадратного) в сечении торса, схожего оформления головы, маленькими кружочками показаны также и груди [Досымбаева, 2002, цвет. фото, рис. 14а] (рис. 7,6). Однако у изваяния из Шольсай-1, в отличие от кременских скульптур, изображены руки с сосудом, что кардинально разъединяет эти типы.

Нельзя не упомянуть и одно изваяние из Донецкого областного краеведческого музея. Если бы не отсутствие на нем грудей и пупка, то оно было бы очень близкой аналогией кременскому. Правда, на голове донецкого изваяния четко виден сфероконический шлем в отличие от не столь ясной формы головных уборов кременских изваяний (рис. 7,7 ).

Датировка изваяний. Поскольку существует устойчивая априорная версия, что мужские кременские и саратовские изваяния были изготовлены в раннезолотоордынское время, напрашивается мысль: не связано ли отсутствие женских скульптур в Поволжье с распространением ислама. Но в этом случае изваяния логичнее было бы датировать не ранним (2-я - 3-я четверти XIII в.), а уже развитым ордынским временем - серединой XIV в. (от чего авторы отказались), то есть периодом широкомасштабного и стремительного распространения ислама в восточноевропейской степи. Возможно, по этой же причине на саратовских мужских изваяниях изображены вполне реальные женские груди, а не маленькие кружочки ${ }^{18}$ (рис. 7,1,3,4), а также шейные гривны, несравненно более характерные для собственно женских половецких изваяний (рис. 7,2,4).

Феномен изображения женских черт на мужских изваяниях в раннеордынское время можно объяснить компромиссом между исламскими запретами и еще не угасшей или не подавленной тенгрианской традицией поклонения образу женского предка. Впрочем, однозначно связывать рассматриваемое явление с влиянием ислама рискованно, хотя бы потому, что женская грудь нередко встречается и на достоверно мужских (не факт, что старческого возраста) изваяниях, традиционно датирующихся половецким временем, причем в регионах, весьма удаленных от основных центров распространения ислама. Обычно это почти всегда скульптуры стоящего или сидящего типа, то есть полнофигурные изваяния периода расцвета половецкой каменной пластики. А в нашем случае мы, безусловно, имеем дело с более поздней скульптурой столбовидного типа. Возможно, речь в этом случае надо вести также и с точки зрения переосмысления роли женщины в социальной стратификации поздних кочевников в раннеордынское время. Одним словом, эта проблема еще далека от своего разрешения.

Исходя из типологии Г.А. Федорова-Давыдова, существенно детализированной С.А. Плетневой, кременские изваяния следовало бы отнести к самым поздним группам половецкой скульптуры - типу III по Г.А. Федорову-Давыдову (1966) или типу VII по С.А. Плетневой (1974). Напомним, что это изваяния «особого, сильно упрощенного стиля, в котором скульптор пренебрегал даже такими деталями, как руки, ограничиваясь передачей объема головы и остав- 
ляя туловище в виде прямоугольного в сечении каменного столба» [Федоров-Давыдов, 1966, с. 168]. По сути, так же характеризует этот тип и С.А. Плетнева: «....круглые стеловидные изваяния. У всех статуй этого типа довольно тщательно проработанные голова и лицо... Тулово VII типа - в виде антропоморфного столба, то есть оно лишено рук и ног. ...Эти изваяния мы считаем логическим завершением эволюционного ряда» [Плетнева, 1974, с. 61]. «Характерно, что в основных районах расселения половцев, - отмечает С.А. Плетнева, - их сравнительно немного. Зато в поволжских степях статуи VII типа преобладают. ...поволжские изваяния изготовлены примитивнее и небрежнее статуй того же типа, сделанных мастерами центральных половецких областей (Донца и даже Северного Кавказа). Объясняется это “периферийностью” скульптурной поволжской школы, а также, вполне возможно, более поздним происхождением поволжских статуй сравнительно с центрально-половецкими. Статуи VII типа появились вместе с отхлынувшим в XIII в. в поволжские степи населением, а их немногочисленность говорит о быстром исчезновении этого обряда под давлением внешнеполитических обстоятельств» [Плетнева, 1974, с. 65].

Содержание вышеприведенных цитат Г.А. Федорова-Давыдова и С.А. Плетневой таково, что, хотели того исследователи или нет, фактически их мнение совсем не исключало вероятности функционирования половецких каменных изваяний также и в раннеордынское время. Более того, ученые сами обосновывают возможные причины, по которым упрощенные изваяния наиболее поздних типов могли бы появиться именно в это время в Нижнем Поволжье. Однако остается еще много вопросов. В частности, Г.А. Федоров-Давыдов построил довольно простую схему перехода к поздним типам, выдвинув всего лишь один аргумент изображение сосуда без рук как рудимент развитого типа. При этом в качестве примера он привел всего одно изваяние [Федоров-Давыдов, 1966 , с. 185 , рис. 28,2$]$. Несравненно более развернутую картину предлагала С.А. Плетнева [Плетнева 1974, с. 65]. На примере женских изваяний из Одесского музея она показала пять переходных стадий развития каменной половецкой скульптуры.
Как нам представляется, в этом вопросе необходимо четко различать время изготовления изваяний и время их функиионирования по назначению. В отличие от вещей из погребений, являющихся закрытыми комплексами, святилища с изваяниями таковыми не являются. Поскольку считается, что оба кременских изваяния не просто однотипны, а аналогичны друг другу [Плетнева, 1974, c. 109], скорее всего они являются продуктом работы одного мастера-камнетеса. Время, затраченное на изготовление скульптур, невозможно установить наверняка, но это явно не один день, а возможно, и не один месяц. К тому же мастер, несомненно, не мог делать две скульптуры одновременно. Поэтому тогда, когда одно изваяние уже начало использоваться по прямому назначению, второе еще находилось в процессе своего изготовления. Но это еще не самое главное. В рассматриваемом случае мы имеем крайне нестандартную, возможно уникальную, ситуацию, когда одно изваяние, уже будучи разбитым, перестало использоваться по прямому назначению, а втоpoe, оставшись целым, скорее всего, даже и не начало использоваться и практически сохранило свое первоначальное состояние «из мастерской». До настоящего времени это, возможно, единственный подобный случай во всей восточно-европейской степи. Поскольку взаимосвязь между скульптурами несомненна, случайным не может быть ничего: ни разбитое состояние одной скульптуры, ни замечательная сохранность другой. И это обстоятельство требует своего объяснения.

Согласно классификации, разработанной С.В. Гуркиным, все половецкие святилища делятся на два типа: I - устроенные на поверхности курганов, II - святилища-ямы, устроенные в насыпях курганов [Гуркин, 1987, с. 108]. Но кременский комплекс не находит себе место в этой схеме и явно относится к памятникам смешанного типа: первоначально он функционировал как святилище типа I, а несколько позднее - как тип II. Возможно, это вообще единственный памятник такого рода. Особая уникальность кременского комплекса состоит также и в том, что изваяния сопровождаются археологически целой красноглиняной корчагой. Ее поздний характер относительно времени изготовления изваяний бесспорен. 
Это обстоятельство существенно расширяет возможности определения времени функционирования всего комплекса. Несомненно, что по мере накопления фактического материала данная ситуация прояснится в лучшую сторону.

Линия развития восточно-европейской скульптуры, разработанная ведущими исследователями, в целом довольно логична, но вряд ли она является единственно возможной или неизменной. Ключевым моментом в попытке решения данного вопроса может быть обсуждение конкретных находок половецких скульптур, в частности переходных от развитых образцов к более поздним. Совсем недавно при попытке найти изваяниям, подобным кременским, соответствующее типологическое и хронологическое место среди тюркской каменной пластики, один из авторов столкнулся с немалыми трудностями [Евглевский, Пилипенко, 2012а, с. 135-148; 2012б, c. 189-198]. Аналогичные проблемы проявились также и в связи с подготовкой к публикации кременских изваяний, что в целом и вызвало необходимость дополнительной работы. Соглашаясь в целом с концепциями Г.А. Федорова-Давыдова и С.А. Плетневой, заметим, что особенности иконографии этих изваяний (груди и пупок, изображенные в виде небольших кружочков) не позволяют с полной уверенностью относить их к наиболее поздним типам половецкой скульптуры. Подобные затруднения неудивительны, поскольку спустя много лет после выхода в свет книг Г.А. Федорова-Давыдова (1966) и С.А. Плетневой (1974) источниковая база позднекочевнической скульптуры увеличилась весьма значительно. Появление переходных звеньев в типологии с неизбежностью предопределяет необходимость уточнения некоторых моментов уже существующей схемы развития половецкой скульптуры, касающихся, в частности, вопросов определения времени изготовления и функционирования наиболее поздних типов.

Г.А. Федоров-Давыдов и С.А. Плетнева, объясняя появление позднеполовецких изваяний в Поволжье, главный упор сделали на тезис о переселении туда кочевников из Поросья в раннеордынское время [Федоров-Давыдов, 1966, с. 152; Плетнева, 1974, с. 65]. Действительно, традиционные перемещения кочевников в собственно половецкое время су- щественно не влияли на общий ход развития их скульптуры. Но насильственные массовые перемещения ордынского времени, безусловно, имели уже более серьезные последствия для подвластного монголам населения. Как известно, это отразилось на социальной стратификации кочевников, вероисповедании и т. д. Не стало исключением и искусство, в том числе и ваяние статуй.

Но в данном случае проблема состоит в том, что в Поросье изваяния, обнаруженные in situ (то есть на курганах), вообще не известны. Они не обнаружены там ни на полях, ни в балках, ни за пределами курганов, их нет даже в музеях. Несколько изваяний есть в частных коллекциях, например в с. Веремиевка Черкасской области, но они привезены туда из западных районов Херсонской, Запорожской и Днепропетровской областей. Почему же тогда появление в Поволжье изваяний упрощенного типа было увязано Г.А. ФедоровымДавыдовым и С.А. Плетневой с предположительной миграцией в этот регион именно поросских кочевников, вообще не имевших практики изготовления каких-либо статуй? Очевидно, что ответить на такой вопрос в 60-70-е гг. $\mathrm{XX}$ в. было довольно сложно, хотя бы потому, что в то время еще не были составлены карты распространения в Половецкой степи святилищ с достоверными паспортными данными. А изваяния на картах С.А. Плетневой, как известно, в значительной степени отражают лишь количественные данные наличия статуй в отдельных музейных собраниях [Плетнева, 1974, рис. 1-3], в большинстве своем либо не имеющих достоверных паспортных данных, либо полностью их утративших. Основная масса половецких скульптур музейных собраний Москвы, Санкт-Петербурга, Киева и Одессы перевезена из Северного Приазовья, Левобережья Нижнего Поднепровья и Нижнего Дона - регионов, где и было сосредоточено основное большинство этих культовых памятников. Понятно, что источники, не имеющие привязок хотя бы к регионам, не могут решать проблем, связанных с вопросами перемещения населения.

Конечно, курганы с изваяниями in situ (учитывая мощный исламский фактор) в Поволжье могли просто не сохраниться, но таких памятников, за небольшим исключением, 
нет и в соседних с Поволжьем регионах. Ближайший район, где было обнаружено относительно много изваяний (около 20), расположен довольно далеко к западу от Волги - в междуречье Хопра и Северского Донца [Цыбин, 2000 , с. 134], но их привязки к курганам и даже к местности также далеко не всегда точны. Курган из ст-цы Кременская, хотя и был раскопан с позиций нашего времени методически не совсем удачно, представляет собой уникальный случай документально зафиксированной географической привязки, позволяющий не только уточнить вопрос о хронологической позиции одного из позднейших типов половецкой скульптуры, но и более обстоятельно рассмотреть культовые памятники кочевников всей восточно-европейской степи.

Еще одним фактором, позволяющим отвергнуть «поросскую» версию, является то, что в Поросье в предордынское время преимущественно проживали потомки печенегов и огузов, изготовление изваяний которыми в полной мере никем еще не было доказано ${ }^{19}$. В Поволжье изваяния вытесывались или половцами, или родственными им иными кыпчакскими этническими группами, переселившимися сюда из каких-то других регионов, но только не из Поросья. Теоретически исходными регионами могли быть любые соседние районы - Северное Приазовье, Правобережье Нижнего Дона или даже Южное Приуралье. Об этом, например, свидетельствуют отдельные признаки (кружочки-груди), которые имеются также и на изваяниях Урала. Однако по сочетанию уже двух или больше признаков какой-либо регион исхода кочевников в Поволжье пока не определяется. При всей неясности этого вопроса меньше всего можно говорить о местном сложении иконографии поволжских изваяний. В регионе просто нет традиции ваяния кыпчакско-половецкой скульптуры, на почве которой мог бы произойти переход к ее последнему этапу. Впрочем, отсутствие специального анализа иконографии изваяний Поволжья, Урала и северо-западных районов Казахстана делает это предположение таким же шатким, как и ничем не оправданную версию о возможности переноса традиции ваяния в Поволжье из Поросья.

В отдельных регионах степи, очевидно, могли складываться свои специфические осо- бенности угасания традиции использования изваяний, но происходило это не везде одинаково. Тенденция, лишь в целом, была общей (подверженная стадиальным законам традиционного искусства) во всей Половецкой степи, и так называемая упрощенность иконографии ваяния неминуемо шла сначала по линии утраты деталей костюма, исчезновения рук и ног, половых черт - к едва уловимой антропоморфности монолита. В свете этого кременские изваяния находятся в несколько обособленном положении. Наличие на них некоторых специфических особенностей, о которых речь шла выше (сочетание груди и пупка в виде маленьких кружочков, отсутствие гривен и кос, а также, возможно, изображенная на голове шапочка, а не шлем), не позволяет ставить их в один ряд как с саратовскими, так и с некоторыми другими известными изваяниями, также относящимися к позднейшей группе половецкой скульптуры. Но это не значит, что позднюю дату кременских изваяний можно отрицать. Просто известные ныне позднейшие типы, видимо, не вполне одновременны друг другу и, соответственно, не синхронны. Кременские изваяния в ряду наиболее поздних занимают относительно более раннюю хронологическую позицию. Вышеуказанные особенности этих изваяний характерны не только для наиболее поздних типов, но и для некоторых типов, однозначно относящихся к домонгольскому времени. Оригинальность кременских изваяний заключается в соединении на них двух иконографических решений. С одной стороны, это относительно ранние признаки второй половины XI - XII в.: изображения маленьких кружочков-грудей и пупка, отсутствие канонического (статичного) положения рук, свойственного развитой восточно-европейской скульптуре. С другой стороны, это наиболее поздние черты: тщательная проработка головы (особенно лица) в стиле развитой объемной скульптуры, материал - мергель, четырехгранный столбовидный торс. К этому важному заключению один из авторов пришел уже в ходе подготовки первого варианта настоящей статьи [Евглевский, 2014].

Выводы. Подытоживая анализ памятника, следует отметить, что изваяние, оказавшееся в кургане 4 разбитым, в открытом общедоступном виде могло функционировать 
лишь в домонгольское время, то есть не позднее конца 1-й трети ХІІІ в., и было целенаправленно разбито, скорее всего, появившимися в Восточной Европе монголами. Целое изваяние, в отличие от разбитого, было размещено в кургане 4 «скрытно». С самого начала оно, по видимому, даже не предназначалось для открытого доступа. Подобное могло иметь место только в самом начале раннеордынского времени, то есть не ранее середины 2-й четверти XIII века. Поскольку иконография обеих скульптур практически одинакова, наиболее предпочтительной датой их изготовления и начала функционирования одной из скульптур можно считать финал домонгольского времени - середину 2-й четверти или начало 2-й трети XIII века. Дату завершения функционирования всего комплекса, в целом, можно сдвигать к концу 2-й четверти - середине XIII века. Верхняя дата пока не очень понятна и все еще требует своего уточнения. Наиболее поздним культовым действием оказалось размещение в кургане 4 примерно в середине XIII в., но не позднее конца 3-й чет- верти XIII в., большой красноглиняной гончарной корчаги, изготовленной в каком-то, пока еще не установленном, раннеордынском провинциальном гончарном центре.

Очевидно, мы имеем дело с феноменом, который нельзя объяснить простым эволюционным развитием ранее устоявшихся типов скульптур. Появление в Поволжье позднейших типов половецких изваяний, возможно, следует объяснять не только фактом вынужденного переселения кочевников в этот регион из не совсем пока понятных каких-то иных районов достаточно обширной Половецкой степи и, как следствие, образовавшейся в регионе «периферийности» относительно более ранней и более развитой скульптуры центрально-половецкой школы, уже переставшей к этому времени полноценно функционировать, а какими-то иными причинами. Такими причинами могли быть только военно-политические события, связанные с появлением в степях Восточной Европы монголо-татар и началом формирования основ золотоордынского государства. 


\section{ИЛЛЮСТРАЦИИ}

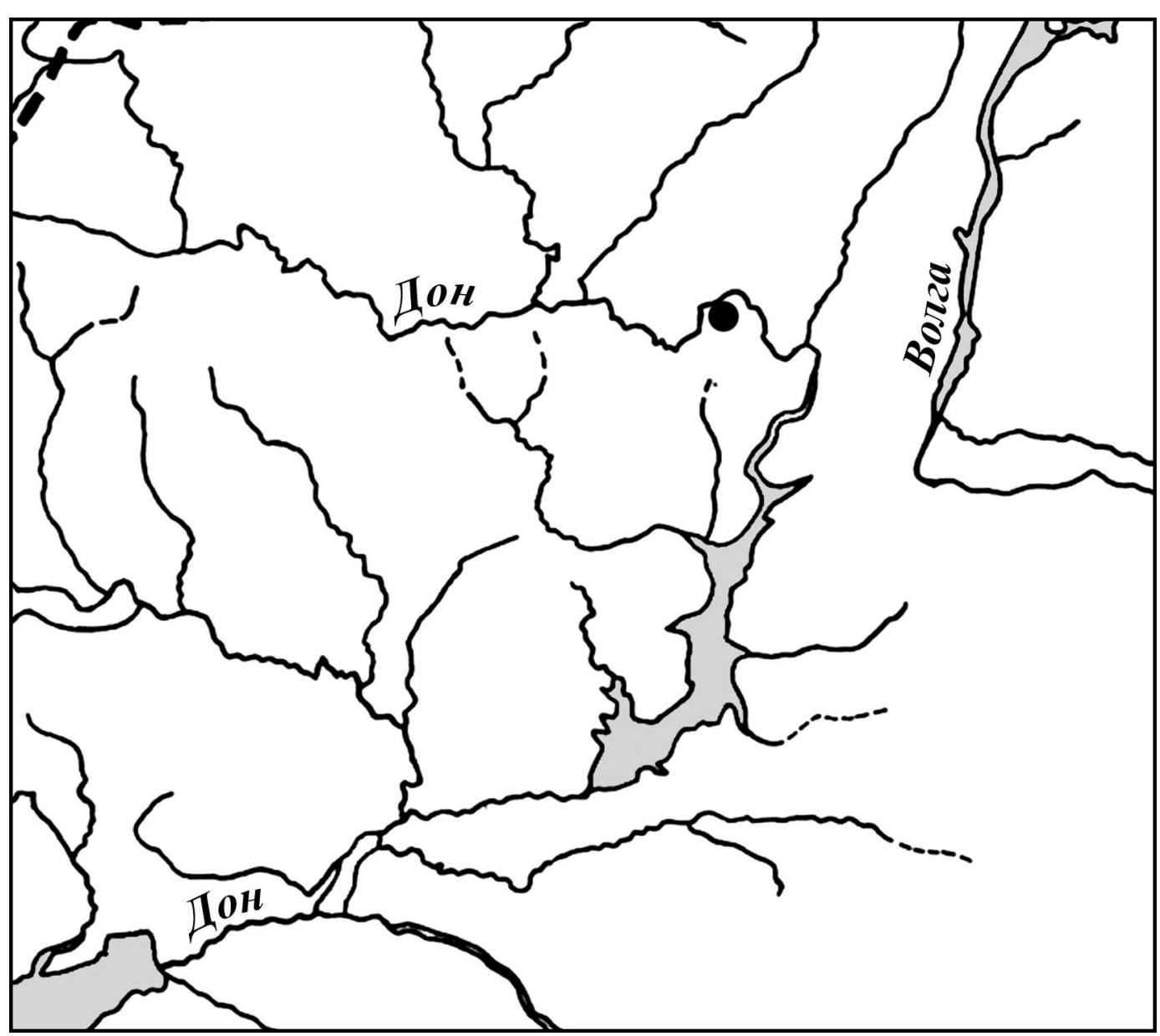

Рис. 1. Карта местонахождения курганной группы Кременская I 


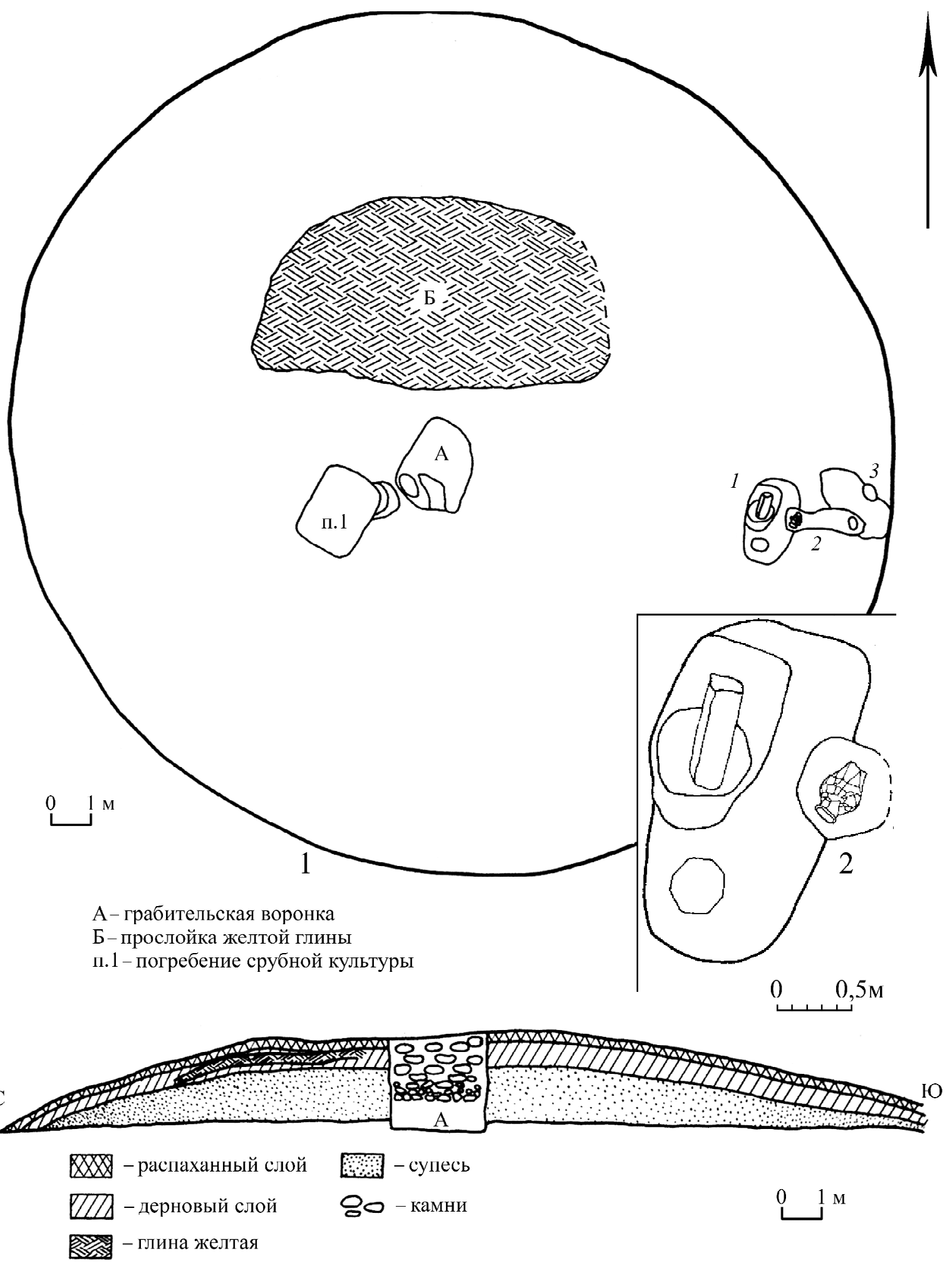

Рис. 2

1. Общий план и западная сторона бровки кургана 4 группы І у ст-цы Кременская:

1 - яма с основанием изваяния; 2 - яма с корчагой; 3 - зольное пятно.

2. Яма с основанием изваяния и яма с корчагой.

Источник: [Шилов, 1960б] 
A.V. Evglevskiy, E.V. Kruglov. Statues and Large Earthenware Pot from Barrow Mound near Kremenskaya Village
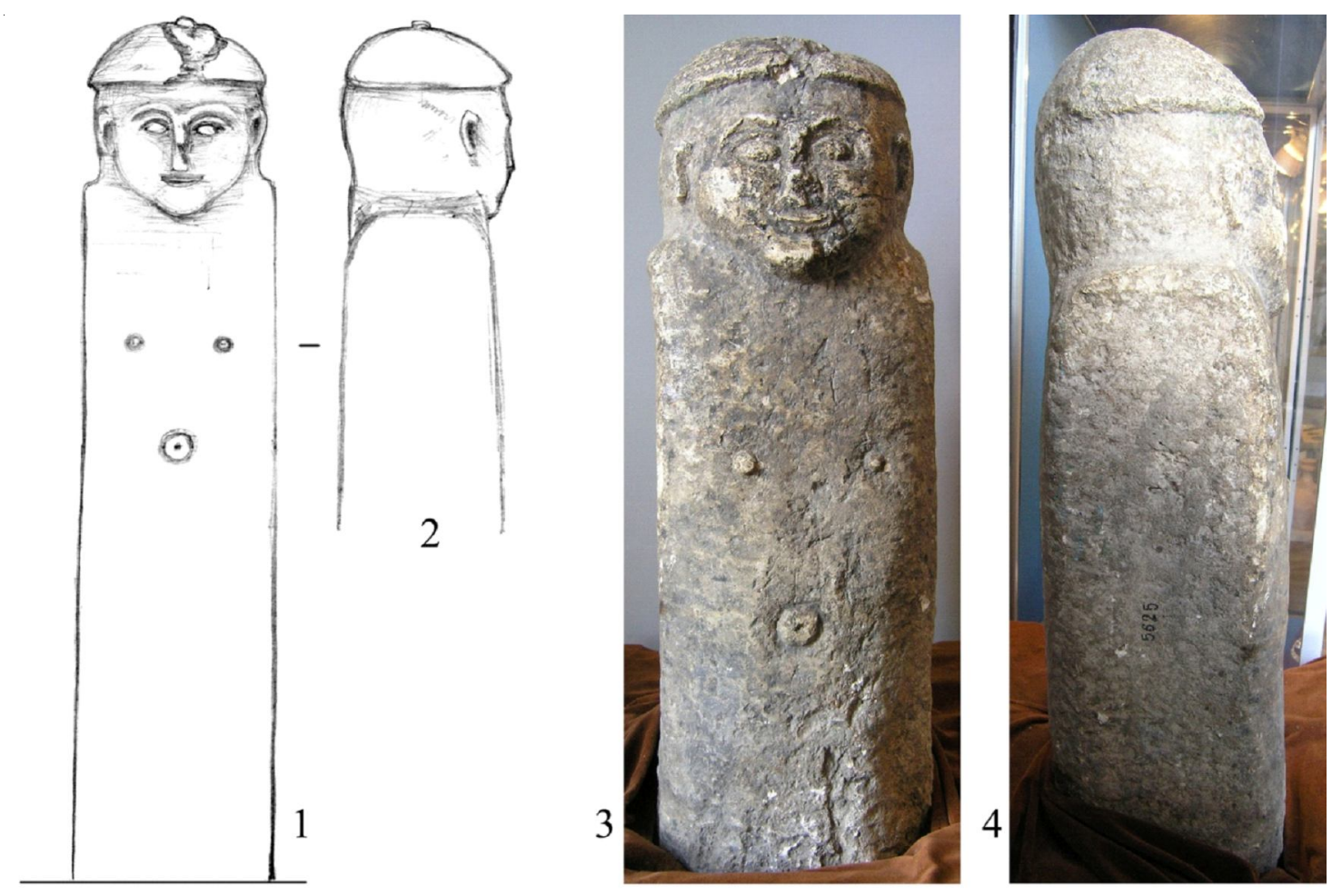

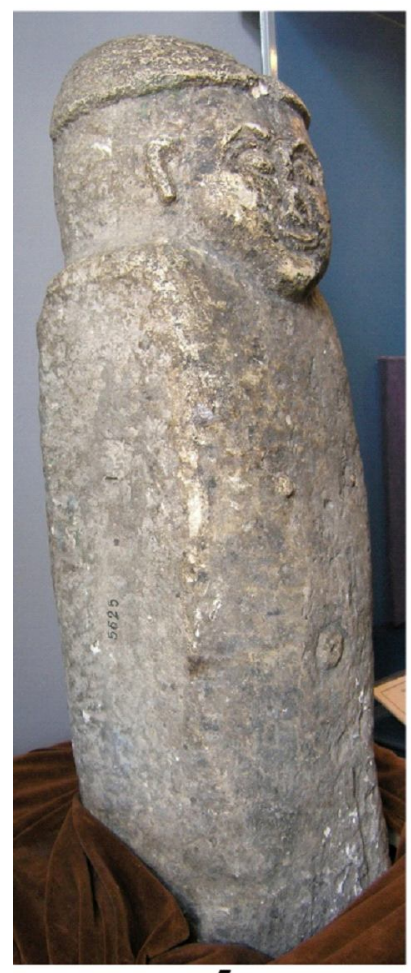

5

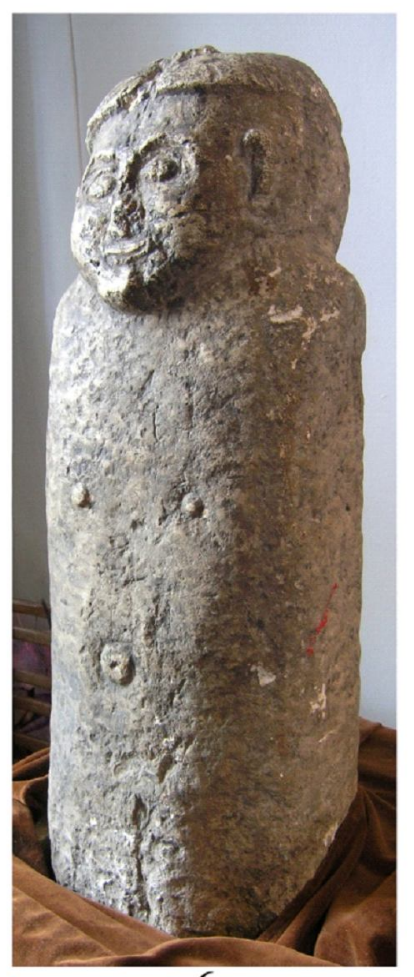

6

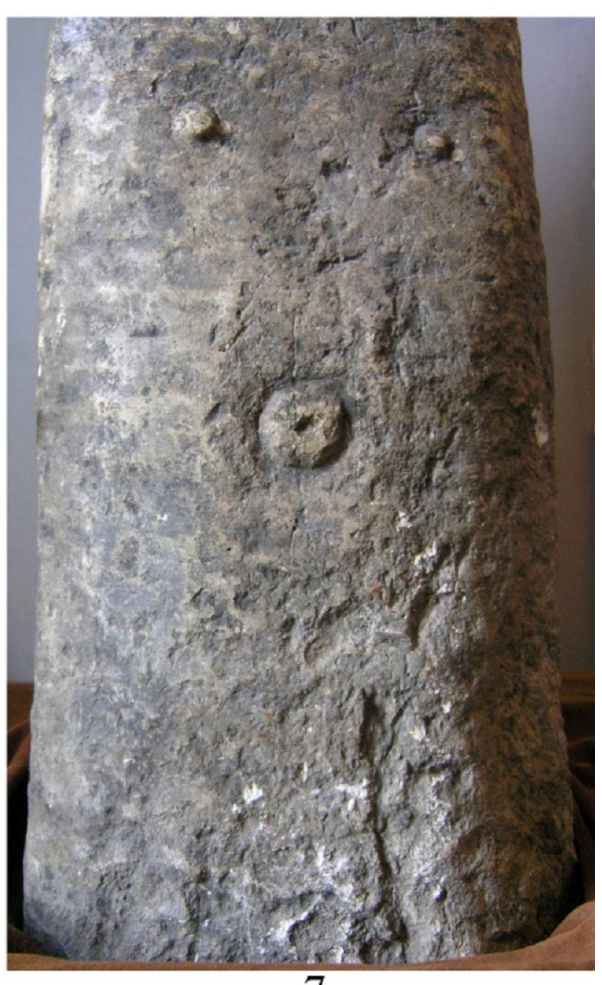

7

Рис. 3. Изваяние 1 из кургана 4 группы І у ст-цы Кременская 
А.В. Евглевский, Е.В. Круглов. Изваяния и корчага из кургана у станицы Кременская на Нижнем Дону

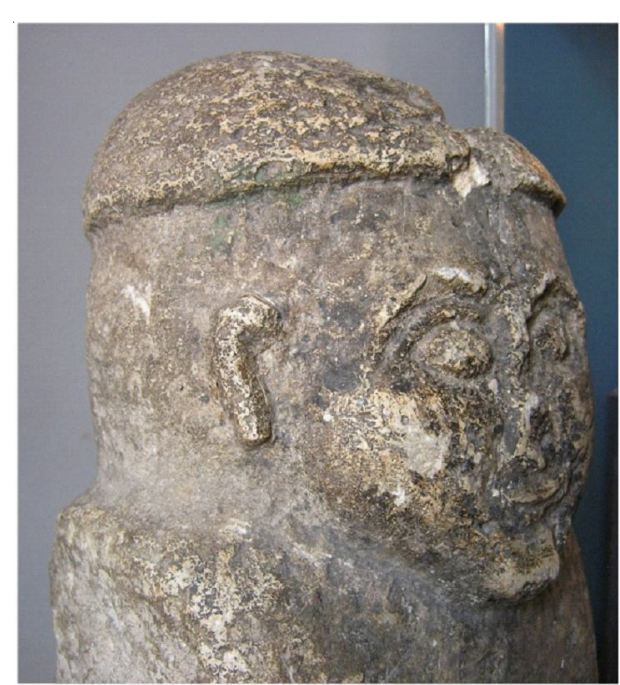

1

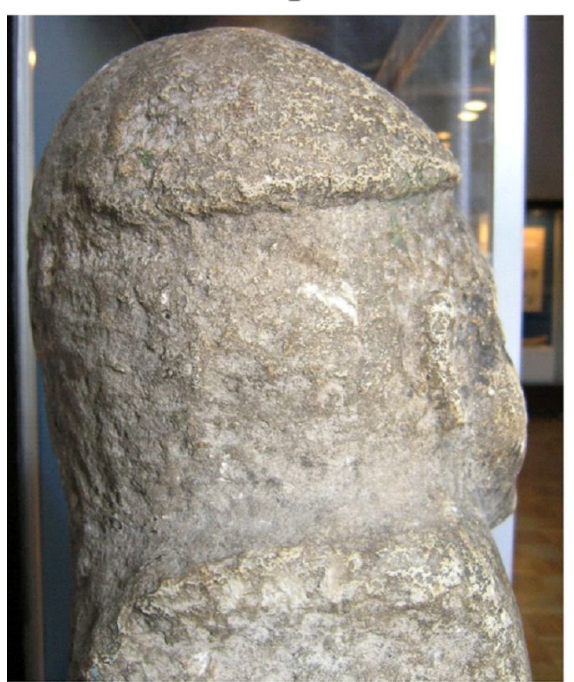

3

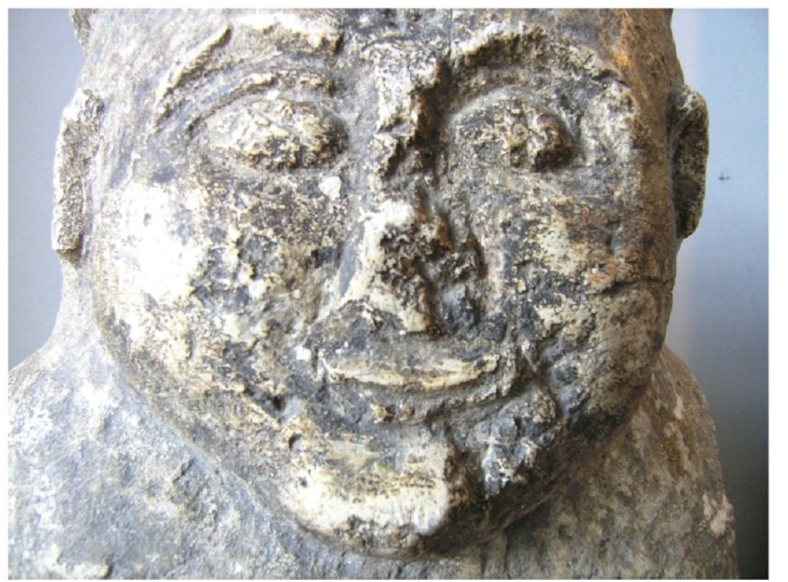

5

Рис. 4. Изваяние 1 из кургана 4 группы І у ст-цы Кременская 

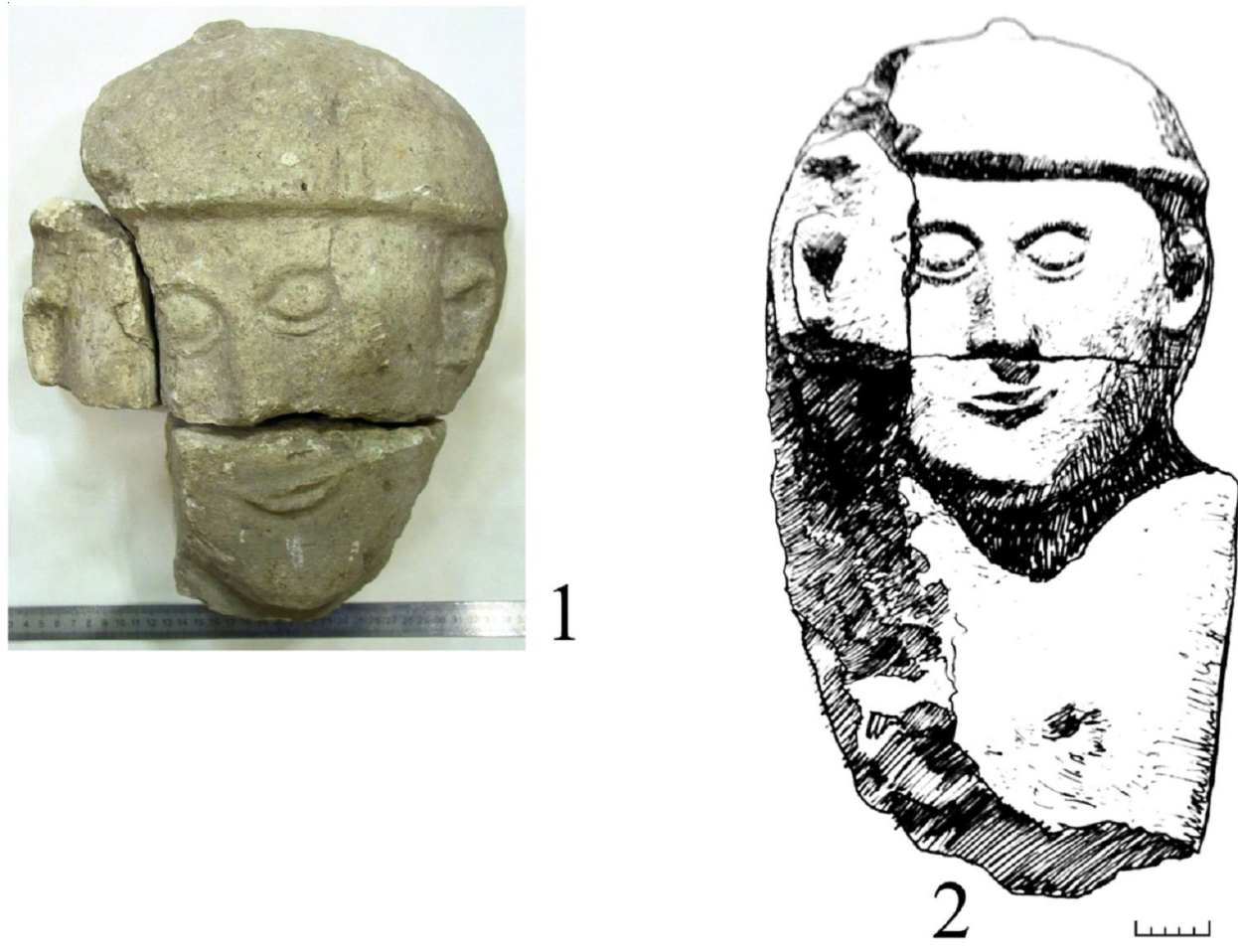

Рис. 5. Изваяние 2 из кургана 4 группы І у ст-цы Кременская (источник: Отчет В.П. Шилова, см.: [Шилов, 1966а]) 
A.B. Евглевский, E.В. Круглов. Изваяния и корчага из кургана у станицы Кременская на Нижнем Дону
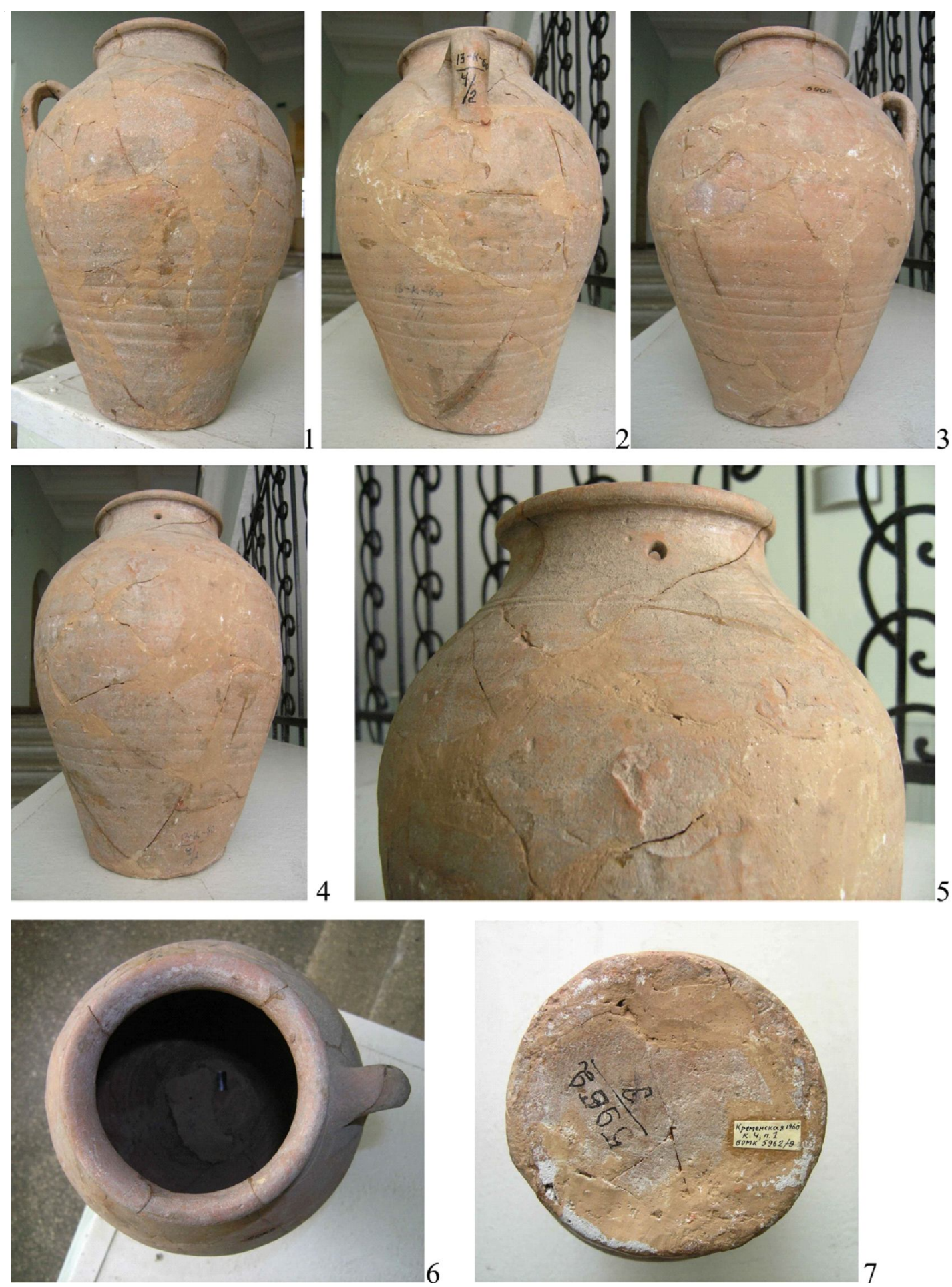

Рис. 6. Корчага из кургана 4 группы І у ст-цы Кременская 

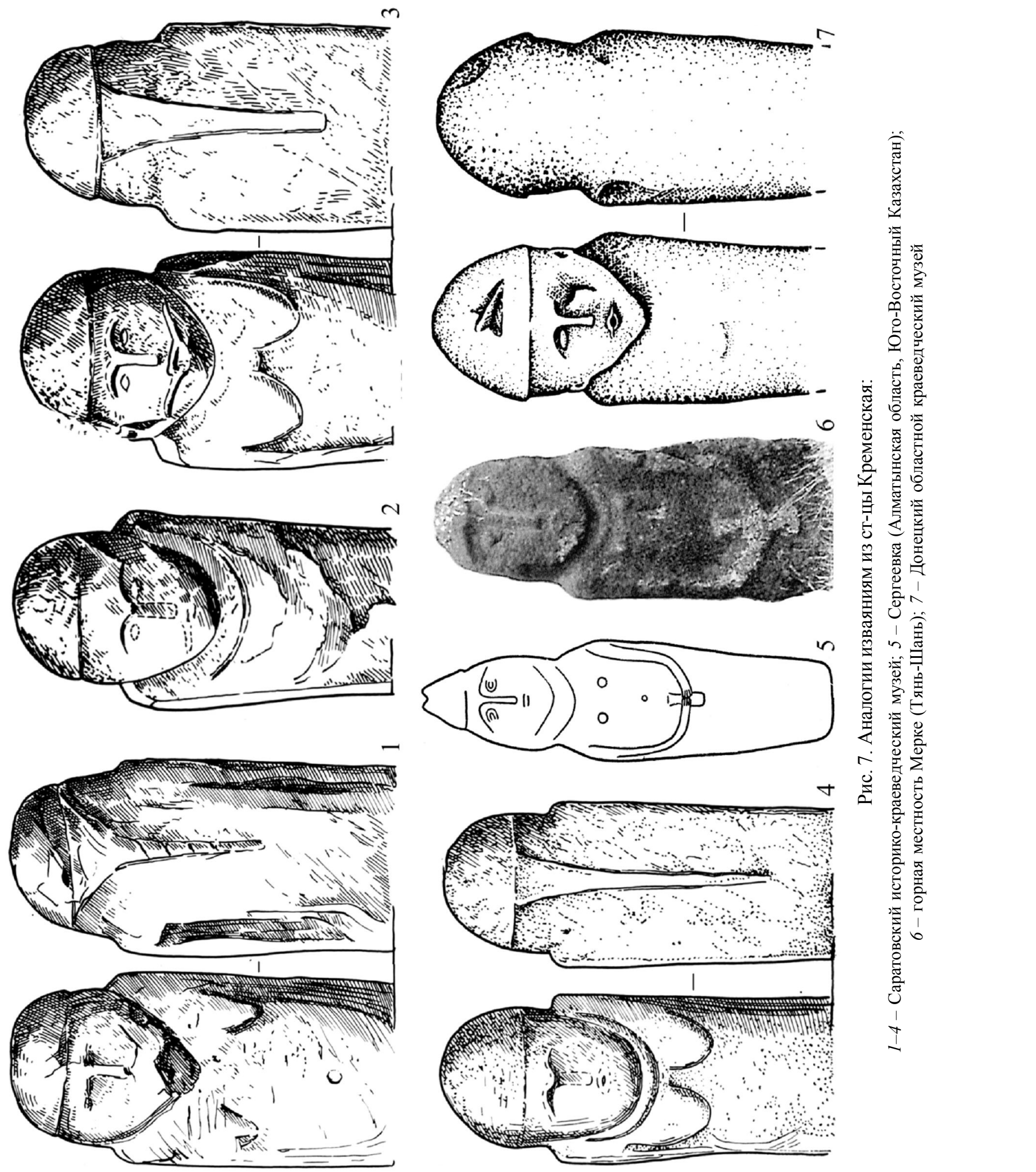


\section{ПРИМЕЧАНИЯ}

1 Данная статья является переработанным и существенно дополненным вариантом статьи, ранее изданной одним из авторов [Евглевский, 2014, c. 263-282]. Расширена историография, отмечены все основные упоминания о памятнике, учтены ранее изданные в научной и научно-популярной литературе фотографии и рисунки изваяний. Добавлена и уточнена информация об археологическом контексте памятника. Расширен анализ стратиграфии кургана, ямы «А» и всех ям «погребения 2», в результате чего одни проблемные вопросы получили иную трактовку, а другие оказались значительно развернуты. В качестве аналогий рассмотрены практически все известные случаи находок ям на святилищах поздних кочевников, в той или иной степени заполненных мергелем или камнем и связанных с установкой каменных изваяний. По иному рассмотрено возможное расположение в ямах «погребения 2» изваяний, разбитого и целого, а также глиняной корчаги, позволившее существенно уточнить понимание хронологии комплекса в целом.

${ }^{2}$ Относительно часто в насыпи или ровике курганов встречаются фрагменты керамики, в то время как другие вещи крайне редки.

${ }^{3}$ В составе Астраханской археологической экспедиции ЛОИА АН СССР в 1960 г. под руководством В.П. Шилова принимали участие 13 научных сотрудников, многие из которых долгие годы весьма тесно и плодотворно были связаны с археологией. Среди них: И.П. Засецкая (Государственный Эрмитаж), Л.Я. Маловицкая (библиотека Российской академии художеств), В.А. Филипченко (Астраханский государственный краеведческий музей), В.И. Мамонтов (Сталинградский, ныне Волгоградский ГСПУ им. А.С. Серафимовича), В.И. Артемьев (ЛОИА АН СССР - Маргианская археологическая экспедиция, г. Ташкент).

${ }^{4}$ Целое изваяние и разбитые части второго ныне хранятся в фондах ВОКМ и имеют общий учетный номер (инв. № 5625).

${ }^{5}$ В.П. Шилов обычно придерживался довольно четкой практики обозначения глубин обнаруженных основных погребений от «уровня горизонта». Глубины впускных погребений, а также разнообразных комплексов и ситуаций чаще всего он указывал от «уровня современной поверхности». Однако для первого варианта не всегда понятно, от какого «горизонта» шел отсчет: то ли от уровня древней погребенной почвы, то ли от уровня материка. Для второго варианта тоже не всегда ясно, от какой точки мог идти отсчет - от местоположения центрального репера, обычно совпадавшего с наивысшей точкой кургана, или же от условной точки, располагавшейся над местом обнаружения конк- ретного погребения, комплекса или ситуации. Учитывая эти неопределенности, уровень глубин мы вынуждены указывать в первоначальной авторской формулировке.

${ }^{6}$ На авторском плане кургана обозначение «С» не указано.

${ }^{7}$ Информация о наличии в заполнении ямы «А» меловых камней, по В.П. Шилову, аналогичных материалу каменных изваяний, обнаруженных около кургана, имеет для темы исследования не последний интерес. Нельзя исключать того, что действия, связанные с заполнением ямы «А» камнями, могли происходить в эпоху Средневековья и иметь отношение к половецкому святилищу. Хотя связь изваяний и каменного заполнения ямы «А» остается лишь предположительной, авторы посчитали необходимым, как минимум, упомянуть об этом и попытаться смоделировать наиболее приемлемые варианты происходивших обрядовых действий. В связи с этим проанализированы известные случаи обнаружения в одном кургане каменных половецких изваяний и расположенных отдельно от них непогребальных ям-ситуаций с теми или иными каменными конструкциями.

${ }^{8}$ В первой версии анализа материалов святилища у ст-цы Кременская [Евглевский, 2014, с. 264] зольное пятно на общем плане кургана 4 обозначено как «яма 3 », что не совсем верно: «яма 3 », как таковая, В.П. Шиловым вообще не выделялась. Обнаружить яму в распаханном слое на глубине всего 0,1 м от поверхности - практически нереально.

${ }^{9}$ Местонахождение нижней части разбитого изваяния в настоящее время нам не известно.

${ }^{10}$ Корчага хранится в фондах ВОКМ (инв. № 5962/9).

${ }^{11}$ Благодарим за содействие хранителя фондов археологии ВОКМ Н.В. Хабарову.

${ }^{12}$ Образцы для петрографического анализа не взяты из-за нежелания нанести изваянию отличной сохранности повреждение. То, что это мергель, определяется по слегка стесанным участкам. Косвенно это подтверждает второе изваяние, на местах излома которого хорошо виден мергель (мажется).

${ }^{13}$ Благодарим И.В. Волкова - сотрудника Института «Наследие» (г. Москва) за консультации, выполненные по цветным фотографиям корчаги.

${ }^{14}$ Письма И.В. Волкова к А.В. Евглевскому от 07.082007 г. и 11.112013 г.

${ }^{15}$ Письмо И.В. Волкова к А.В. Евглевскому от 12.122013 г.

${ }^{16}$ К сожалению, саратовские изваяния в силу их недоступности не осматривались. Сопоставление проведено по рисункам из книги С.А. Плетневой [Плетнева 1974, с. 189, табл. 73, № 1250-1254].

${ }^{17} \mathrm{C}$ большой долей вероятности можно предполагать, что и на разбитом изваянии были изобра- 
жены кружочки-выпуклости, обозначающие мужскую грудь и пупок.

${ }^{18}$ На мужских изваяниях мужская грудь показывалась довольно часто. Целью такого изображения была демонстрация силы и мужественности воина. До распространения развитой объемной (круглой, по С.А. Плетневой) скульптуры и на позднем этапе на мужских изваяниях грудь показывалась маленькими кружочками-выпуклостями, схожими с теми, которые имеются на кременских статуях. Таких изваяний довольно много не только на Урале и в Казахстане, они есть также и в Северном Приазовье.

${ }^{19}$ Едва ли не единственную попытку такого рода предприняла Л.С. Гераськова [Гераськова, 1991], но эта проблема еще весьма далека от какого-либо решения.

\section{СПИСОК ЛИТЕРАТУРЫ}

Волков И. В., Ларенок П. А. (1988). Половецкое святилище на Нижнем Дону // Вестник МГУ. Серия 8, История. № 1. С. 86-87.

Гераськова Л. С. (1991). Скульптура середньовічних кочовиків степів Східної Європи. Киев : Наукова думка. $132 \mathrm{c.}$

Гугуев Ю. К., Мирошина Т. В. (2002). Половецкое святилище-яма с каменной статуей и человеческими жертвоприношениями у села Бешпагир в Ставропольском крае // Донская археология. № 3-4. С. 53-67.

Гуркин С. В. (1987). Половецкое святилище с деревянными изваяниями на Нижнем Дону // CA. №4. C. 100-109.

Досымбаева А. М. (2002). Мерке- сакральная земля тюрков. Тараз : Сеним. 107 с.

Евглевский А. В. (1996). Культовое захоронение половецких каменных изваяний в святилище на Мечетном поле в Донбассе // Древние культуры Восточной Украины. Проблемы изучения и правовой охраны археологического наследия. Луганск : Изд-во ВУГУ. 241 с.

Евглевский А. В. (2014). Изваяния и корчага из кургана у станицы Кременская на Нижнем Дону: К проблеме завершающего этапа изготовления половецкой скульптуры // Степи Европы в эпоху средневековья. Т. 13. Золотоордынское время / отв. ред. А. В. Евглевский. Донецк : ДонНУ. 459 с.

Евглевский А. В., Пилипенко Д. В. (2012а). Тюркские изваяния «погрудного» типа: пример практической атрибуции // Степи Европы в эпоху средневековья. Т. 10. Половецкое время / отв. ред. А. В. Евглевский. Донецк : ДонНУ. 353 с.
Евглевский А. В., Пилипенко Д. В. (2012б). Уникальное стеловидное тюркское изваяние из Васильевки (Северное Приазовье) // Степи Европы в эпоху средневековья. Т. 10. Половецкое время / отв. ред. А. В. Евглевский. Донецк : ДонНУ. 353 с.

Кокорина Н. А. (2002). Керамика Волжской Булгарии второй половины XI - начала XV в. (К проблеме преемственности булгарской и булгаро-татарской культур). Казань : Ин-т истории. 384 с.

Круглов Е. В. (2001). Поволжье в половецкое время, XI-XIII вв. // Культура средневековых кочевников и городов Золотой Орды. Каталог. Волгоград. $32 \mathrm{c}$.

Кубышев А. И., Дорофеев В. В., Шилов Ю. А., Полин С. В., Шевченко Н. П., Черных Л. А., Марченко И. Л., Солтыс О. Б., Сердюков В. В., Якунов С. А. (1980). Отчет о работах Херсонской археологической экспедиции ИА АН УССР у сс. Волчанск, Владимировка, Красное Акимовского района Запорожской области и у сс. Громовка, Сивашовка Новотроицкого района Херсонской области в 1980 г. // Национальный архив ИА АН Украины. Киев. № 1980/15.

Кубышев А. И., Дорофеев В. В., Симоненко А. В., Куприй С. А., Ковалев Н. В., Амирханов А. Ш. (1985). Отчет о работах Херсонской археологической экспедиции в Херсонской области в 1985 году // Национальный архив ИА АН Украины. Киев. № 1985/7.

Кубышев А. И., Болтрик Ю. В., Симоненко А. В., Фиалко Е. Е., Куприй С. А., Ковалев Н. В., Лысенко Г. И. (1986). Отчет о работах Херсонской археологической экспедиции в зоне строительства Каховской оросительной системы в Херсонской, Запорожской областях УССР в 1986 г. // Национальный архив ИА АН Украины. Киев. № 1986/13.

Материкин В. В., Комиссарова Е. В. (2005). Волгоградский областной краеведческий музей: 90 лет служения отечеству (1914-2004). Очерк истории. Волгоград : Панорама. 192 с.

Моруженко А. А., Зарайская Н. П., Санжаров С. Н., Посредников В. А., Косиков В. А. (1983). Отчет об археологических раскопках курганов в зоне строительства мелиоративных систем на территории Амвросиевского, Марьинского, Першотравневого и Славянского районов Донецкой области в 1983 г. // Национальный архив ИА АН Украины. Киев. № 1983/50.

Нарожный Е. И. (2003). О половецких изваяниях и святилищах XIII-XIV вв. Северного Кавказа и Дона // Степи Европы в эпоху средневековья. Т. 3. Половецко-золотоордынское время / отв. 
ред. А. В. Евглевский. Донецк : Изд-во ДонНУ. $493 \mathrm{c}$.

Плетнева С. А. (1974). Половецкие каменные изваяния // Археология СССР. САИ. Вып. Е4-2. М. : Наука. 200 с.

Полидович Ю. Б., Усачук А. Н., Кравченко Э. Е., Подобед В. А. (2013). Исследования курганов группы Попов Яр-2 в Донецкой области // Археологический альманах. Донецк : Донбасс. № $30.319 \mathrm{c}$.

Привалов А. И., Андриенко В. П., Моруженко А. А. (1978). Отчет новостроечной экспедиции Донецкого госуниверситета за 1978 г. // Национальный архив ИА АН Украины. Киев. № 1978/73.

Ремизов С. О., Хабарова Н. В. (2009). Кременская // Археологическая энциклопедия Волгоградской области. Волгоград : Изд-во ВолГУ. 336 с.

Ремизов С. О., Хабарова Н. В. (2016). Кременская // Археологическая энциклопедия Волгоградской области. 2-е изд. Волгоград : Изд-во ВолГУ. $336 \mathrm{c.}$

Ситников А. В. (1995). Население Нижнего Поволжья в кыпчакское время // «Проблемы взаимодействия национальных культур» («Межэтнические общения в полиэтническом регионе») : сб. тез. регион. науч. конф. Ч. 2. Астрахань : АГПИ им. С.М. Кирова. 117 с.

Ситников А. В. (2009). Половецкие изваяния // Археологическая энциклопедия Волгоградской области. Волгоград : Изд-во ВолГУ. 336 с.

Ситников А. В. (2016). Половецкие изваяния // Археологическая энциклопедия Волгоградской области. 2-е изд. Волгоград : Изд-во ВолГУ. $336 \mathrm{c}$.

Ситников А. В., Антюфеев О. В. (2000). Половецкие изваяния Волго-Донского междуречья и Нижнего Поволжья // Вопросы краеведения. Вып. 6 . Материалы краеведческих чтений, посвященных 75-летию областного общества краеведов. Волгоград : Изд-во ВолГУ. 484 с.

Скрипкин А.С. (2005). История Волгоградской земли до основания города. Волгоград : Изд-во ВолГУ. 204 с.

Скрипкин А. С. (2008). История Волгоградской земли до Золотой Орды. Волгоград : Издатель. 208 с.

Федоров-Давыдов Г. А. (1966). Кочевники Восточной Европы под властью золотоордынских ханов. М. : Изд-во МГУ. 275 с.

Хабарова Н. В. (2001). Каталог // Культура средневековых кочевников и городов Золотой Орды. Каталог. Волгоград. 32 с.

Хабарова Н. В., Петров П. А., Кривошеева А. В. (2013). Каталог археологических находок из фондов Волгоградского областного краеведческого музея // Археологическое наследие Волгоградской области : К 100-летию Волгог- радского краеведческого музея. Волгоград : Издатель. 288 с.

Хлебникова Т. А. (1984). Керамика памятников Волжской Болгарии. К вопросу об этнокультурном составе населения. М. : Наука. 240 с.

Хлебникова Т. А. (1988). Неполивная керамика Болгара // Город Болгар: Очерки ремесленной деятельности. М. : Наука. 280 с.

Цыбин М. В. (2000). Юго-Восточная граница Руси накануне монгольского нашествия (история развития идеи) // Евразийская степь и лесостепь в эпоху раннего средневековья. Археология восточноевропейской лесостепи. Вып. 14. Воронеж : Изд-во ВГУ. $152 \mathrm{c.}$

Швецов М. Л. (1979). Половецкие святилища // Советская археология. № 1. С. 199-209.

Шер Я. А. (1966). Каменные изваяния Семиречья. М. ; Л. : Наука. 140 с.

Шилов В. П. (1960а). Отчет о раскопках Астраханской экспедиции в 1960 г. // Архив ИА РАН. Р-1. № 2155.

Шилов В. П. (1960б). Приложение к отчету о раскопках Астраханской экспедиции в 1960 г. // Архив ИА РАН. Р-1. № 2155a.

\section{REFERENCES}

Volkov I.V., Larenok P.A. (1988). Polovtsian Sanctuary on the Lower Don. Bulletin of MSU, Series 8, History, no. 1, pp. 86-87. (in Russian).

Geraskova L.S. (1991). Sculpture of Medieval Nomads of Eastern European steppes. Kyiv, Naukova Dumka Publ. 132 p. (in Ukrainian).

Guguev Yu.K., Miroshina T.V. (2002). Polovtsian pitsanctuary with a stone statue and the human sacrifices at the village of Beshpagir in the Stavropol region. Don archaeology, no. 3-4, pp. 53-67. (in Russian).

Gurkin S.V. (1987). Polovtsian Sanctuary with Wooden Statues on the Lower Don. Soviet archaeology, no. 4, pp. 100-109. (in Russian).

Dosymbaeva A.M. (2002). Merke is a Sacral Land of the Turkic Peoples. Taraz, Senim Publ. 107 p. (in Russian).

Evglevskiy A.V. (1996). Religious burial of the Polovtsian stone statues on sanctuary at Mechetnoie Pole in Donbas. Ancient cultures of Eastern Ukraine. Problems of study and legal protection of archaeological heritage. Lugansk, Izd-vo VUGU. 241 p. (in Russian).

Evglevskiy A.V. (2014). Statues and large earthenware pot from barrow near Kremenskaya village on Lower Don: On concluding stage of making of Polovtsian Statues. The European steppes in the Middle Ages. Vol. 13. The Golden Horde times. Doneck, DonNU Publ. 459 p. (in Russian). 
EvglevskiyA.V., PilipenkoD.V.(2012a). Turkic statues of "breast" kind: Example of practical attribution. The European steppes in the Middle Ages. Vol. 10. The Polovtsian times. Doneck, DonNU Publ. 353 p. (in Russian).

Evglevskiy A.V., Pilipenko D.V. (2012б). Unique stelalike Turkic statue from Vasilievka (Northern Azov Sea Littoral). The European steppes in the Middle Ages. Vol. 10. The Polovtsian times. Doneck, DonNU Publ. 353 p. (in Russian).

Kokorina N.A. (2002). Pottery of Volga Bulgharia of the $2^{\text {nd }}$ half of the $11^{\text {th }}$ - the early $15^{\text {th }}$ century (On problem of succession of the Bulghar and Bulghar-Tatar cultures). Kazan, Institut istorii Publ. 384 p. (in Russian).

Kruglov E.V. (2001). The Volga reaches during the Polovtsian times, $11^{\text {th }}-13^{\text {th }}$ centuries. Culture of Medieval Nomads and towns of the Golden Horde. Catalogue. Volgograd. 32 p. (in Russian).

Kubyshev A.I., Dorofeev V.V., Shilov Yu.A., Polin S.V., Shevchenko N.P., Chernyh L.A., Marchenko I.L., Soltys O.B., Serdyukov V.V., Yakunov S.A. (1980). Report on works of the Kherson archaeological expedition of Institute of Archaeology of Academy of Sciences of the UkrSSR near villages of Volchansk, Vladimirovka, Krasnoe of the Novotroitsky District of the Kherson Region in 1980. National archive of IA AS of Ukraine. Kiev, no. 1980/15. (in Russian).

Kubyshev A.I., Dorofeev V.V., Simonenko A.V., Kupriy S.A., Kovalev N.V., Amirhanov A.Sh. (1985). Report on works of the Kherson archaeological expedition in the Kherson region in 1985. National archive of IA AS of Ukraine. Kiev, 1985, no. 1985/7. (in Russian).

KubyshevA.I., BoltrikYu.V., Simonenko A.V., Fialko E.E., Kupriy S.A., Kovalev N.V., Lysenko G.I. (1986). Report on works of the Kherson archaeological expedition in the construction zone of the Kakhovka irrigation system in the Kherson, Zaporozhye regions in 1986. National archive of IA AS of Ukraine. Kiev, no. 1986/13. (in Russian).

Materikin V.V., Komissarova E.V. (2005). Volgograd Regional Museum: 90 years of service to the Motherland (1914-2004). Essay of history. Volgograd, Panorama. 192 p. (in Russian).

Moruzhenko A.A., Zarayskaya N.P., Sanzharov S.N., Posrednikov V.A., Kosikov V.A. (1983). Report on the archaeological excavations of burial mounds in the area construction of drainage systems on the territory of Amvrosiivka, Maryinskiy, Pershotravnevyy and Slavyanskiy districts of Donetsk region in 1983. National archive of IA AS of Ukraine. Kiev, no. 1983/50. (in Russian).
Narozhnyy E.I. (2003). On Polovets statues and sanctuaries of the $13^{\text {th }}-14^{\text {th }}$ centuries: the North Caucasus and Don Areas. The European steppes in the Middle Ages. Vol. 10. The Polovets and Golden Horde times. Donetsk, DonNU Publ. 493 p. (in Russian).

Pletneva S.A. (1974). The Polovtsian stone statues. Archaeology of the USSR. Collection of archaeological sources. Iss. E4-2. Moscow, Nauka Publ. 200 p. (in Russian).

Polidovich Yu.B., Usachuk A.N., Kravchenko E.E., Podobed V.A. (2013). Explorations of barrow group of Popov Yar-2 in the Donetsk Region. Archaeological literary miscellany. Donetsk, Donbass Publ, no. 30. 319 p. (in Russian).

Privalov A.I., Andrienko V.P., Moruzhenko A.A. (1978). Report of Novotroitskoe expedition by Donetsk State University in 1978. National archive of IA AS of Ukraine. Kiev, no. 1978/73. (in Russian).

Remizov S.O., Khabarova N.V. (2009). Kremenskaya. Archaeological encyclopedia of the Volgograd Region. Volgograd, Izd-vo VolGU.336p. (in Russian).

Remizov S.O. Khabarova N.V. (2016). Kremenskaya. Archaeological Encyclopedia of the Volgograd Region. $2^{\text {nd }} e d$. Volgograd, Izd-vo VolGU. 336 p. (in Russian).

Sitnikov A.V. (1995). Population of the Lower Volga reaches in the Qipchaq time. Collected theses of regional scientific conference "Problems of interaction of national cultures" ("Interethnic conversations in polyethnos region”). Part 2. Astrakhan, AGPI im. S.M. Kirova. 117 p. (in Russian).

Sitnikov A.V. (2009). The Polovtsian statues. Archaeological encyclopedia of the Volgograd Region. Volgograd, Izd-voVolGU. 336 p. (in Russian).

Sitnikov A.V. (2016). The Polovtsian Statues. Archaeological encyclopedia of the Volgograd Region. $2^{\text {nd }}$ ed. Volgograd, Izd-vo VolGU. 336 p. (in Russian).

Sitnikov A.V., Antyufeev O.V. (2000). The Polovtsian statues of the Volga-Don interfluve and the Lower Volga reaches. Matters of local history. Issue 6. Materials of reading on local history devoted to the $75^{\text {th }}$ anniversary of Regional Society of Local Historians. Volgograd, Izd-vo VolGU. 484 p. (in Russian).

Skripkin A.S. (2005). The history of Volgograd land before the foundation of the city. Volgograd, Izd-vo VolGU. 204 p. (in Russian).

Skripkin A.S. (2008). The history of Volgograd region from the Stone Age to the Golden Horde. Volgograd, Izdatel Publ. 208 p. (in Russian).

Fedorov-Davydov G.A. (1966). Eastern European Nomads under the rule of the Golden Horde 
Khans. Moscow, Izd-vo MGU. 275 p. (in Russian).

Khabarova N.V. (2001). Catalogue. Culture of Medieval Nomads and towns of the Golden Horde. Catalogue. Volgograd. 32 p. (in Russian).

Khabarova N.V., Petrov P.A., Krivosheeva A.V. (2013). Catalogue of the archaeological artifacts from funds of the Volgograd Regional Museum. Archaeological heritage of the Volgograd Region. To the $100^{\text {th }}$ anniversary of the Volgograd Regional Museum. Volgograd, Izdatel Publ. 288 p. (in Russian).

Khlebnikova T.A. (1984). Pottery from the sites of Volga Bulgharia. On issue of ethno-cultural composition of population. Moscow, Nauka Publ. 240 p. (in Russian).

Khlebnikova T.A. (1988). Non-glaze pottery of Bolgar. Town of Bolgar: Essays on crafts. Moscow, Nauka Publ. 280 p. (in Russian).
Tsybin M.V. (2000). South-Eastern border of Rus on the eve of the Mongol Invasion (History of development of the idea). Eurasian steppe and forest-steppe during the Early Middle Ages. Archaeology of the Eastern European foreststeppe. Iss. 14. Voronezh, Izd-vo VGU. 152 p. (in Russian).

Shvetsov M.L. (1979). The Polovtsian sanctuaries. Soviet Archaeology, no. 1, pp. 199-209. (in Russian).

Sher Ya.A. (1966). The Stone statues of Zhetysu. Moscow, Leningrad, Nauka Publ. 140p. (in Russian).

Shilov V.P. (1960a). Report on excavations of the Astrakhan expedition in 1960. Archive of Institute of Archaeology of RAS, R-1, no. 2155. (in Russian).

Shilov V.P. (1966b). Appendix to report on excavations of the Astrakhan Expedition in 1960. Archive of Institute of Archaeology of RAS, R-1, no. 2155a. (in Russian).

\section{Information about the Authors}

Aleksandr V. Evglevskiy, Senior Researcher, Archaeological Research Group of the Faculty of History, Donetsk National University, Universitetskaya St., 24, 83001 Donetsk, Donetsk People's Republic, a.yevglevsky@gmail.com.

Evgeniy V. Kruglov, Secretary of Volgograd Regional Department of All-Russian Community for Nature and Culture Monuments Protection, Kaleganova St., 9, office 107, 400081 Volgograd, Russian Federation, khasar@vlpost.ru.

\section{Информация об авторах}

Александр Викторович Евглевский, старший научный сотрудник археологической научно-исследовательской группы исторического факультета, Донецкий национальный университет, ул. Университетская, 24, 83001 г. Донецк, ДНР (Донецкая Народная Республика), a.yevglevsky@gmail.com.

Евгений Викторович Круглов, секретарь Волгоградского регионального отделения Всероссийского общества охраны памятников истории и культуры (ВРО ВООПИиК) Волгоградской области, ул. им. Калеганова, д. 9, оф. 107, 400081 г. Волгоград, Российская Федерация, khasar@vlpost.ru.

Citation. Evglevskiy A.V., Kruglov E.V. (2016). Statues and Large Earthenware Pot from Barrow Mound Near Kremenskaya Village on Lower Don: on Concluding Stage of Making of Polovtsian Sculptures (II). The Lower Volga Arhaeological Bulletin, vol. 15, no. 1, pp. 40-71. (in Russian). 